\author{
Зоран Чворовић \\ Универзитет у Крагујевиу, Правни факултет у Крагујевиу \\ Међународни иентар за православне студије, Нии \\ e-mail:zcvorovic@jura.kg.ac.rs; zoranrcvorovic@gmail.com
}

\title{
КРИВИЧНОПРАВНА ЗАШТИТА ЖЕНЕ У РУСКОМ СРЕДЊОВЕКОВНОМ ПРАВУ
}

\begin{abstract}
Апстракт: Рад се бави правним положајем жене у средњовековној Русији из угла кривичних прописа који су штитили живот, част и здравље жене. На основу анализе бројних правних споменика, као и споменика правне праксе, у раду се на примеру руског средњовековног права преиспитује теза феминистичке друштвене теорије да је христијанизачија довела до погоршана правног и друштвеног статуса жене.

Кључне речи: руско средњовековно право, правни положај жене, христијанизачија, силовање, увреда части.
\end{abstract}

\section{Увод}

У оквиру радикалног (radical feminism) или родног феминизма (gender feminism), као једне од двеју водећих струја у савременом феминистичком покрету, ${ }^{1}$ формулисан је у другом таласу феминизма седамдесетих година прошлог века појам „културе силовања“ (rape culture). ${ }^{2}$ Тим појмом се означава култура која својим колективним уверењима, вредностима, митовима и популарним стереотипима оправдава сексуално насиље над женама, истовремено га сматрајући неизбежним у историји. Благонаклон однос „културе силовања“ према сексуалном насиљу над женама огледа се, између осталог, и у несразмери која постоји „у кривичном правосуђу између великог броја сексуалних напада на жене и невеликог броја притварања, судског гоњења и осуда нападача.“ Према мишљењу радикалних феминисткиња за искорењивање „културе силовања“ важне су како мере социјалног инжењеринга које треба да обезбеде женама „правне, економске и друштвене привилегије мушкарца,“ тако и „супростављање механизмима културе силовања.“3

Кључни инструмент „културе силовања“ представљају „митови о силовању“ (rape myths) ${ }^{4}$ који у савременим друштвима оправдавају насиље над женама, а чије порекло радикалне феминисткиње проналазе у патријархалној култури и монотеистичким религијама. Према овом схватању, патријархат као социјално-политичка доктрина и културни систем ,производи и одржава злоупотребу и насиље према женама структурним (преко друштвених институција) и идеолошким утицајем (процесом

1 Антонић 2011, 9-10.

2 Field 2004, 174.

3 Исто.

4 Schmidt 2004, 191-193. 
социјализације).“5 Доминација мушкараца у патријархату испољава се у свим друштвеним односима, па је жена „другоразредни пол чак и у породичној структури, независно од тога што трајање породице биолошки зависи од жене.“6 Радикалне феминисткиње истичу да је „,андроцентризам монотеистичких религија“ утицао на клир и лаике да „су пре склони да доведу у питање неприкосновеност сексуалног и религиозног интегритета жртве која је преживела силовање, него насилника.“ Истовремено ове ауторке оптужују хришћанске теологе да су вековима уназад у својим списима игнорисали тему силовања, а када су се с тим проблемом сусретали посредством библијских текстова, онда су, наводно, „силовање редефинисали у 'завођење' или 'љубав'.“7 Традиционално схватање силовања које ово кривично дело ограничава искључиво на насилне полне односе ван брака, према водећој радикалној феминисткињи из седамдесетих година прошлог века, Сузан Браунмилер (Susan Brownmiller), потиче из Библије, јер се у њој ,законитим сматра сваки телесни однос у оквиру брачног уговора.“8

Због патријархалне културе и идејне доминације хришћанске Цркве радикалне феминисткиње неретко означавају европско средњовековље за родно место савремене „културе силовања“.9 У мултидисциплинарној научној студији Medieval Misogyny and the Invention of Western Romantic Love, професор Универзитета Јејл Ричард Блох (Richard Howard Bloch), директно доводи у везу мизогини карактер средњовековне културе са хришћанским учењем, јер су, по њему, оци ране Цркве „све што припада сфери женског или естетског обезвређивали у онотолошком смислу,“ док је „право на пуноћу Битија“ имало само оно „што се по њиховом мишљењу налази с оне стране плоти, и што је самим тим по роду мушко." ${ }^{10}$

Истовремено се у научним часописима из области родних студија срећу и радови у којима аутори износе другачије оцене о доприносу хришћанске Цркве кривичноправној заштити жена у државама средњовековне римокатоличке Европе. Тако Стефан Пистоно (Stephen P. Pistono) са Универзитета Висконсин примећује, с једне стране, како извори у већини потврђују ставове феминисткиња да је жена као жртва силовања у средњем веку „пролазила кроз тешке, болне и понижавајуће процедуре, пре него што је могла да подигне оптужницу против нападача,“ али истовремено истиче да се „Црква више од световних власти занимала за судбину жртве у случајевима силовања и отмица“. ${ }^{11}$ Две кључне тезе радикалних феминсткиња у тумачењу односа патријархата и силовања, да су

5 Ignjatović 2018, 265.

6 Terzieva-Artemis 2004, 145-146.

7 Scholz 2004, 20-207; Petričević 2008, 126-127.

8 Brownmiller 1993, 380. Ставови које је 1975. године Сузан Браунмилер изнела у књизи Against Our Will: Men, Women and Rape, преиспитујући историјски наслеђен „мушки“ правни концепт кривичног дела силовања (првобитно као кривичног дела против имовине оца или мужа, а потом као кривичног дела извршеног из страсти, Brownmiller 1993, 17, 23-24), као и традиционалне начине доказивања овог деликта, извршили су револуционарни утицај на законодавство САД. Schmid 2004, 186.

9 Кариса Харис (Carissa Harris) ca Темпл Универзитета из Филаделфије наводи следеће кључне „митове о силовању“ (rape myths) који су формирани у средњем веку, а који по њеном мишљењу и данас оправдавају насиље над женама и отежавају доказивање кривичног дела силовања: жене лажу о силовању, по пророди им је снажнији либидо него мушкарацима и не могу да контролишу своју сексуалност, свакодневно мењају своје мишљење о сексу, да би се силовањем сматрало стварним мора бити доказано физичким повредама и праћено гласним супростављањем жене, која преживљене трауме, уз обилан плач, мора да поновим пред надлежним властима. Harris 2021.

10 Bloch 1991, 46.

11 Pistono 1989, 36, 41. 
у патријархату „жене посматране као својина“ и да су „жене су увек жртве,“ представљају преми Еми Хокс (Emma Hawks) „упрошћено уопштавање."12 Теза о европском средњовековљу као „култури силовања“ релативизују се уравнотеженим закључцима какве је, примера ради, изнела Каролин Дан (Carolina Dunn) у студији Stolen Women in Medieval England: Rape, Abduction, and Adultery, 1100-1500. Ова ауторка указује да се у литератури „средњовековне жене често представљају као жртве“ које „страдају од сексуалног насиља, принудног брака и самовоље мушких сродника и лица од ауторитета.“ Иста ауторка сугерише да би насупрот томе требало говорити „о сложености односа између средњовековних мушкараца и жена,“ јер жене страдају од силовања, али и уговарају отмице и ступају у ванбрачне везе. ${ }^{13}$

После пропасти СССР појављују се у оквиру новооснованих родних студија бројни радови руских феминисткиња, пре свих Наталије Пушкареве (Наталья Львовна Пушкарёва) и њених сарадница, о друштвеном и правном положају жене у средњовековном руском друштву. ${ }^{14}$ У тим истраживањима се друштвени и правни положај жене у средњовековној Русији (Древняя Русь) анализира нарочито из угла паралелног и често противречног утицаја древне претхришћанске патријархалне културе и нове хришћанске етике. Овај период у развитку руског права нуди релативно богату и значајну грађу за расветљавање проблема утицаја Цркве на правни положај жене у средњем веку у државама православног словенског Истока. Зато што је Црква почев од великог кнеза Владимира имала важну улогу, као законодавац и судија, у изградњи правног поретка Кијевске Русије (Киевская Русь), а ту улогу ће углавном задржати и током периода Московске Русије (Московское государство), све до почетка секуларизације и вестернизације под Петром Великим (Пётр I Алексеевич Великий). ${ }^{15}$

Веза између хришћанства и права нарочито је видљива у кривичном праву, пошто држава инкриминисањем одређених радњи штити званични систем вредности једног друштва. Следствено томе, кривични прописи руских правних споменика из периода од XI до XVII века који су штитили живот, телесни интегритет, здравље и част жене имају непроцењиву вредност за оцену правног и уопште друштвеног статуса жене у Кијевској и Московској Русији.

12 Наведено према Dunn 2013, 11-12.

13 Dunn 2013, 195.

14 Пушкарева 1989; Пушкарева 2012, 11-16; Пушкарева 2011. У чланку Белове и Мухинове, написаном у част шездесет година живота Наталије Пушкареве, навдена је целокупна библиографија ове руске пионирке у области родних студија. Белова, Мухина 2019, 15-17.

15 У историји руске државе средњовековна епоха или епоха Древней Руси завршава се крајем XVII века, када с реформама Петра Великог започиње вестернизација и секуларизација руске државе и друштва. Семенникова 2009, 18-195; Чворовић 2018a, 13. Истражујући приватан живот жене у Древној Русији, Пушкарева следи класичну периодизацију руске историје, па епоху Древней Руси временски смешта између „формирања државе $Р y c b$, као доње границе“ и „почетка петровских реформи, као горње границе.“ Притом истиче како је традиционална периодизација руске историје посредно преузета и у истраживањима еволуције социјалног, правног и породичног статуса руских жена од X-XVII века. Следствено, у дугом периоду од X-XVII века за прву тачку преокрета узима се XIII век, „век рађања бројних држава на мапи Древне Русије, када је дословно свака од њих избацила у политичку арену агилну и енергичну женску личност, а често чак и више њих.“ За другу тачка преокрета у овиру периода од X-XVII века узима се средина XVI века, када долази, према Пушкаревој, до „коначног конститусања државе по моделу самодржавне монархије и победе идеје патријархалног поретка у породици и друштву.“ Пушкарева 2011, 9-10. 


\section{Убиство жене}

Руска правда, као најзначајнији староруски правни споменик, регулише убиство жене као посебан облик кривичног дела убиства. Тај пропис се налази у Широј правди ${ }^{16}$ и у зависности од рукописа има другачију нумерацију, ${ }^{17}$ а донекле и различиту садржину. То је навело истраживаче да изведу потпуно опречне закључке о начину кажњавања убиства жене према Руској правди.

Први став наведеног прописа је истоветан у свим рукописима и гласи: „Ако неко убије жену, да се суди исто као да је убио мужа (мушкарца). “18 Из овако јасне одредбе ${ }^{19}$ тешко би се могао извести другачији закључак осим да се према Руској правди убиство слободне жене кажњавало исто као и убиство обичног слободног мушкарца, а за ово кривично дело била је прописана новчана казна (вира) од 40 гривни. ${ }^{20}$ Да су према Руској правди животи мушкарца и жене имали исту вредност, те да се, сходно томе, једнако кажњавало ${ }^{21}$ убиство жене и мушкарца, потврђује и одредба Шире правде о убиству зависног кнежевог или бојарског занатлије и занатлијке: „А за (убиство) занатлију и за занатлијку, 12 гривни“ ( $A$ за ремественика и за ремественицю, то 12 гривенъ). ${ }^{22}$

Забуну међу истраживачима унео је, међутим, кратак и стога нејасан текст другог става прописа о убиству жене, који је у Синодално-Троицкој групи рукописа Шире правде формулисан следећим речима: „ако буде крив, тада полувира 20 гривни“ (аже будеть виноватъ, то пол виры 20 гривенъ). ${ }^{23}$ Из тога су поједини истраживачи извели закључак како је „у Русији, као у сваком феудалном друштву, била озакоњена неравноправност жене, пошто се за њено убиство плаћала двоструко мања казна“, односно полувира од 20 уместо вире од 40 гривни. ${ }^{24}$ Противречност између норме првог става која је налагала да се учиниоцу за убиство жене „суди исто као да је убио мужа (мушкарца)“ и упола блаже казне за убиство жене из другог става ова група истраживача је решавала углавном онако како је то предложио М. Н. Тихомиров (Михаил Николаевич Тихомиров). Према његовом тумачењу право жене на једнаки суд из првог става наведеног прописа Руске правде треба разумети као право на једнака процесна права мушкарца и жене, односно на исти судски

16 Шира редакција Руске правде настала је, према М. Н. Тихомирову, у периоду после смрти Владимира Мономаха, а пре монголске инвазије на Кијевску Русију, између 1125. и 1237. године. Тихомиров 1941, 219.

17 У Карамзиновом рукопису Шире правде који је Владимирски-Буданов објавио у својој чувеној Хрестоматији руских правних споменика, пропис о убиству жене има нумерацију 101, док се у Тројицком рукопису који је с руског издања (Российское законодательство X-XX веков, том I) превео Драган Николић ради о члану 88. Владимирский-Буданов 1876, 69; Николић 2000, 220.

18 Наведено према преводу Тројицког рукописа Шире правде из пера Д. Николића. Николић 2000 , 220. Осим превода појединих прописа Руске правде који су преузети од Д. Николића, сви други преводи руских извора на српски језик у овом раду су ауторови.

19 Први став прописа о убиству жене из Шире правде који је објавио М. Н. Тихомиров према рукопису из Тројицке групе рукописа (XIV век) гласи: „Аже кто оубиеть жену, то тьмь же судом судити, яко же и мужа (чл. 83).“ Тихомиров 1953, 105.

20 Тихомиров 1953, 36; Владимирский-Буданов 1915, 318; Николић 2000, 109, 181-182.

21 Када се говори о једнаком кажњавању убиства жене и мушкарца треба увек имати у виду начело кривичноправне неједнакости сходно коме се почев од Правде Јарослављевича казна за убиство одређивала у зависности од друштвеног статуса убијеног. Владимирский-Буданов 1915, 318 .

22 Тихомиров 1953, 90. Износ вире од 12 гривни говори о зависном статусу ових занатлија, јер да је реч о слободним људима њихово убиство би се кажњавало виром од 40 гривни. Тихомиров 1953, 90; Греков 1940, 59.

23 Тихомиров 1953, 105.

24 Пушкарева 1989, 141; Греков 1940, 79-80. 
поступак, али не и на једнаку казну. У прилог тези о неједнаком кажњавању убиства жене и мушкарца, М. Н. Тихомиров је навео да се „такав обичај (упола блаже кажњавање убиства жене, прим. 3. Ч) одржао и у 19. веку код појединих горштака на Кавказу.“25

То што у рукописима Шире правде Пушкинске групе уместо речи „ако буде крив“ (аже будет виноват) стоји „,ако буде крива“ (аже будет виновата) био је једном броју аутора доказ да је у другом ставу прописа о убиству жене регулисан посебан случај убиства жене код ког је убијена својим претходним понашањем испровоцирала напад, па се стога убица кажњавао полувиром од 20 гривни, а не виром од 40 гривни. ${ }^{26}$ С тим у вези, још је Н. И. Ланге (Николай Иванович Ланге) истицао како се под речју суд „у Правди подразумевала законом одређена казна,“ те да речи то тъмь же судомь судити, яко же и мужа „не подразумевају некакву форму судског поступка, зато што у време Правде нису ни имали било какву представу о формама судског поступка.“ Следствено, „израз то тьмь же судомь судити, яко же и мужа значи да је убица жене подвргаван казни којом се кажњавао и убица мушкарца.“ Полувира из другог става истог прописа била је за Н. И. Лангеа доказ да се у руском праву од времена Владимира Мономаха код кажњавања убиства, како мушкарца тако и жене, почела правити разлика с обзиром на то да ли је убијени претходно изазвао свађу. ${ }^{27}$ Ову тезу Ланге поткрепљује позивањем на одредбу Шире правде о убиству у тучи „без икакве свађе“ (разбой безъ всякоя свады), када учинилац није могао да рачуна на солидарност општине (верв), која је иначе гарантована код других лакших облика убиства. ${ }^{28}$

Слично тумачење дао је и П. Д. Колосовски (Павел Димитриевич Колосовский), истичући како се убица жене према Руској правди кажњавао виром од 40 гривни, осим ако се не ради о случају који је регулисан у другом ставу прописа о убиству жене, „када је жена на неки начин узрок кривичног дела, зато што је својим понашањем допринела реализацији зле намере,“ па се услед постојања такве олакшавајуће околности убица кажњавао полувиром. При томе Колосовски закључује како се ова олакшавајућа околност може правилно разумети тек ако се узме у обзир „степен власти мужа над женом у старој Русији, као и то да се човек нерадо одрицао примене силе у стварима заштите личних права, посебно у породичној сфери.“29 Оригинално тумачење прописа Шире правде о убиству жене дао је својевремено класик руске правноисторијске науке М. Ф. Владимирски-Буданов, који је блаже кажњавање убиства жене полувиром од 20 гривни објашњавао тиме што је наведени пропис у целини (оба става) посвећен „жени као супрузи, коју је муж убио због нарушавања породичних права. “30

Појаву прописа о убиству жене тек у каснијој редакцији Руске правде - Широј правди, Едуард Георгијевски (Эдуард Викторович Георгиевский) објашњава утицајем Цркве, док одсуство овог прописа из Кратке правде сведочи о ставу који је према жени имало руско претхришћанско обичајно право. Она је у том праву, према мишљењу Георгијевског, у сваком случају била деградирана у односу на мушкарца, можда и до те мере да се „жена у староруском праву уопште није признавала, ни као субјект (кривичног дела, прим. аут.) ни као оштећена (у сваком случају до крштења Русије).“31 Исти аутор

25 Тихомиров 1953, 105. Максим Ковалевски је забележио да се код Осетина убиство жене кажњавало упола блаже од убиства мушкарца. Наведено према Греков 1940, 80.

26 Пушкарева 1989, 142.

27 Ланге 1860, 121-122.

28 Исто 1860, 122; Тихомиров 1953, 89; Николић 125, 128-129; Чворовић 2018а, 120.

29 Колосовский $1857,47$.

30 Владимирский-Буданов 1915, 319, 329.

31 Георгиевский 2010, 97-98. 
претпоставља да је до доношења Шире правде живот жене штитио црквени суд. ${ }^{32}$ За такву тврдњу се, међутим, не може пронаћи упориште у одредби црквеног Устава великог кнеза Владимира у којој се наводе сва кривична дела која велики кнез пренео у надлежност црквеног суда. ${ }^{33}$

У каснијим правним споменицима московске епохе не среће се посебан пропис о убиству жене, већ је кривично дело убиства регулисано независно од пола жртве, што свакако показује да је законодавац подједнако вредновао живот жене и мушкарца. Следствено, посебан пропис о убиству жене у Руској правди је правно-технички уникум у историји руског писаног права од XI до XVII века.

Овакав изузетак свакако има везе са казуистичном правном техником која је својствена не само Руској правди, већ и германским leges barbarorum, а у њима се убиство жене регулисало посебним одредбама и притом се неретко оштрије кажњавало од убиства мушкарца. ${ }^{34}$ За разлику од казуистичних прописа варварских закона, у византијским законима се кривично дело убиства регулисало једном општом нормом, независно од пола учиниоца и жртве. ${ }^{35}$

Због оскудних сазнања о руском обичајном праву из периода пре примања хришћанства тешко је поуздано утврдити да ли је пропис Руске правде о једнаком кажњавању убиства жене и мушкарца преузет из руског обичајног права или представља новину. Ипак, чини се мало вероватним да је пре примања хришћанства постојала једнака кривичноправна заштита живота мушкарца и жене, пошто бројни други обичаји сведоче да је жена у руском предхришћанском друштву имала другоразредни положај. На жену

32 Исто, 102.

33 Владимирский-Буданов 1876, 197-198,

34 Пошто припада категорији leges barbarorum, Руској правди су садржински, не и хронолошки, најближи германски leges barbarorum, који су доношени од V до X века и који представљају кодификације обичајног германског права, измењеног пре свега под утицајем хришћанства и римског права које је преношено посредством Цркве (У Рипуарском закону се наглашава да „Црква живи по римском праву“). Зато је оправдано поредити кривичноправну заштиту жене у Руској правди и раним средњовековним германским „правдама“. Крашенинникова, Жидков 2008, 417. У Салијском закону, који је највероватније донет почетком VI века, казна за убиство жене зависила је од тога да ли је убијена жена фертилно способна или није. Убиство жене која не може да рађа кажњавало се као и убиство обичног слободног Франка са 200 солида, док се убиство фертилно способне жене кажњавало са 600 солида (XX, 6, 7). Николић, Ђорђевић 2011, 57. Подаци из „Слова о Игоровом походу“ показују да се и у Древној Русији живот холопке више вредновао него живот холопа, из разлога што је она „рађала радну снагу за феудалца.“ Пушкарева 1989, 140. С тим у вези, с правом се истиче да различито кажњавање убиства жене у зависности од тога да ли је у репродуктивној доби или није, не умањује вредност жене као заштитног објекта у кривичном праву, пошто се ова норма мора сагледати у средњовековним „околностима високе стопе смртности те краткога животног вијека.“ Bartulović, Erent-Sunko, Pezelj 2018, 1107. Према Алеманском закону (Lex Alamannorum) из VIII века за убиство жене плаћало се „двоструко више, него за мушкарца“ (De feminis autem, si ita contigerit, dupliciter conponat qualiter illum virum, 49, 2). И Баварски закон (Lex Baiuvariorum), такође из VIII века, садржи истоветну одредбу о двоструко тежем кажњавању убиства жене у односу на убиство мушкарца и притом објашњава разлог таквој неједнакости: „зато што жена не може да се одбрани с оружјем у рукама и треба да добије двоструку компензацију.“ Једино ако она „пожели да се бије као мушкарац, композиција се не удвостручује“ (De feminis vero eorum, si aliquid de istis actis continxerit, omnia dupliciter conponantur. Dum arma defendere nequieverit, duplicem conpositionem accipiat [Si autem pugnare voluerit per audatiam cordis sui sicut vir, non erit duplex conpositio eius]). Оргиналан латински текст и руски превод Алеманског и Баварског закона у: Данилова 1969, 139, 173, 205, 257.

35 Тако је, примера ради, у Еклоги кривично дело убиства регулисано једним генералним прописом и то независно од пола учиниоца (XVII, 45). Липшиц 1965, 72. 
се гледало као на предмет сексуалног задовољства ${ }^{36}$ и као на ствар која је у својини, не само мужа или оца, већ и шире заједнице - сеоске општине. ${ }^{37}$ При оцени порекла прописа о убиству жене из Руске правде треба имати у виду и да су сви германски варварски закони који пооштрено кажњавају убиство жене у односу на убиство мушкарца донети после примања хришћанства. ${ }^{38}$

У руском средњовековном кривичном праву живот мајке је имао исту вредност као и живот отац. Тако је према чл. 1. и 2. XXII главе Саборног уложенија од 1649. убиство оца и мајке од стране њиховог детета (лично или у својству саучесника) имало карактер квалификованог убиства које је повлачило смртну казну (Будет которой сын или дочь учнит отиу своему или матери смертное убийство, и их за отеческое или за матерне убийство казнить смертию же безо всякия пощады). ${ }^{39} \mathrm{y}$,Домостроју“, главном приручнику породичне етике, економије и педагогије у Московској Русији, посебно поглавље је посвећено томе „како да деца воле и пазе оца и мајку и да им се повинују и поштују их у свему.“"40

Док је према Саборном уложенију убиство мужа од стране жене имало својство квалификованог облика кривичног дела убиства за које се изрицала квалификована

36 Пре примања хришћанства међу Русима је била раширена полигамија. Тако су према, летописцу Нестору, Древљани, Радимичи и Вјатичи живели „као зверови“ и „брак код њих није постојао,“ док су, насупрот томе, Пољани знали за „стид“ и „брачне обичаје.“ Абрашкевич 1904, 469. Руски кнежеви, бојари и трговци имали су хареме са бројним робињима-наложницама, а сам велики кнез Владимир је пре крштења имао осамсто наложница за себе и за дружину и по речима летописца бr несыт блуда, приводя к себъ мужескія жены и дъвицы растляя. Карташев 1993, 245-246, 248; Ярмонова 2013, 97. Да су полигамија и наложништво са робињама (холопкама) практиковани и после примања хришћанства сведочи одредба Руске правде која регулише наследноправни положај деце коју господар добије са робињом. Николић 2000, 222; Абрашкевич 1904, 477.

37 У Русији се дуго задржао древни обичај према коме је момак после просидбе девојке из исте сеоске општине био дужан да части, у новцу или натури, друге момке из тог села. У неким руским губернијама приликом просидбе плаћала се такса симптоматичног назива - коснаго (коса као симбол чедности). По Абрашкевичу наведени обичаји воде порекло из предхришћанског доба и сведоче да се жена третирала као својина заједнице - сеоске општине. Поједини извори, додуше сасвим ретки, говоре да су кнежеви пре христијанизације имали ius primae noctis, а да је такса свадбеное која се плаћала за свадбу, а која је укинута у XVIII веку у време царице Катарине, заправо била замена за древно „право прве брачне ноћи“ којим су располагали руски кнежеви пре примања хришћанства. Абрашкевич 1904, 473-474.

38 О томе какав положај је могла имати жена у словенском и германском обичајном праву пре христијанизације може се донекле посредно закључити и на основу одредби староиндијског Закона Ману, пошто су у њему сачуване норме древне индовропске обичајноправне традиције (од II века пре н. е. до II века после н. е). У староиндијском праву жена је сматрана својином мужа, над којом је он имао власт и после своје смрти, због чега удовице не само да се нису удавале, већ су се неретко самоспаљивале на сахрани свог мужа (сати). Жена се могла продати, а за било какво непристојно понашање жене муж је имао право да је јавно бичује. Крашенинникова, Жидков 2008, 156-157. Обичај спаљивање удовица заједно за умрлим мужем постојао је и код Словена, Германа и Трачана. Жена прељубница се код Германа, према Тациту, ,препушта мужу: он жени одреже косе, скине је до голе коже и пред рођацима истера из куће, па је онда шибом гони кроз цело село.“ Тасіt 1969, 12, 89.

39 Пре доношења Саборног уложенија од 1649. године на злочин убиства родитеља примењивале су се одговарајуће одредбе Крмчије. Томсинов 2011, 250-251; Чворовић 2013, 345.

40 Као корелат моралној обавези деце да поштују и слушају оца и мајку, стајала је обавеза мајке, а нарочито оца, да „децу своју васпитавају у сваком добру и страху Божијем“. Домострой 2014, 47$48,52-53$. 
смртна казна, која се извршавала закопавањем живог учиниоца у земљу ${ }^{41}$ ( $A$ будет жена учинит мужу своему смертное убийство, или окормит его отравою, а сыщется про то допряма, и ей за то казнити, живу окопати у землю, XXII, 14), ${ }^{42}$ убиство мужа од стране жене није регулисано овом кодификацијом. ${ }^{43}$ То не значи, међутим, да се такво убиство није кажњавало. С тим у вези, Владимирски-Буданов (Михаил Флегонтович Владимирский-Буданов) указује како се у руским законским изворима и судској пракси не може наћи доказ да је мужу признато право убиства жене прељубнице. Тако је 1664. године извесни Ивашка, који је убио жену због блудног живота, осуђен на казну јавног бичевања. На основу тога исти аутор закључује, да „у сваком случају и такво блаже кажњавање показује да убиство жене од стране мужа због прељубе јесте кривично дело, а не право мужа.“"44 Да су судије код одређивања казне за убиство жене пре свега водиле рачуна о претходном женином владању, показује један случај из 1674. године у коме је муж који је убио супругу зато што је сакрила два аршина сукна осуђен на казну сакаћења, тако што му је одсечена лева рука и десна нога. ${ }^{45}$ Једном речју, ,у пракси се женоубицама казна одређивала у зависности од мотива и околности кривичног дела, али никада се није кажњавао смртном казном. “46

Код кривичног дела убиства жене које изврши њен муж писци Саборног уложенија, како је већ примећено, ${ }^{47}$ нису следили извор из кога су иначе преузели највише нормативног материјала, Литвански статут од 1588 . године, ${ }^{48}$ пошто се у њему убиство жене од стране мужа кажњавало смртном казном. ${ }^{49}$ Московски законодавац у овом случају није следио ни византијско законодавство, јер се, примера ради, у Еклоги, а потом и у Прохирону, тровање кажњавало смртном казном када отров да „жена мужу или муж жени. “50 Квалификујући убиство мужа од стране жене као знатно теже кривично дело од убиства жене од стране мужа писци Саборног уложенија су се, по речима Колосовског, водили конвенцијама свог времена. Узимајући у виду да је жена у Московској Русији дуговала послушност мужу, убиством мужа она је „показивала виши степен изопачене воље, грубо рушећи све моралне везе и обзире, не само захтеве природе, него чак и оне освештане религијом, и опште појмове и схватања јавног мњења.“51 Законодавац је код процене тежине овог дела дао приоритет субјективној страни деликта, имајући у виду, између осталог, и то да је у пракси жена често убијала мужа због прељубе, што је овом деликту давало карактер квалификованог облика убиства из ниских побуда. С друге стране, убиство жене се у Московској Русији углавном третирало, како од стране

41 Овај облик извршења смртне казне задржан је до указа из 1689. године. У пракси су били чести случајеви помиловања жене осуђене за убиство мужа, које је за последицу најчешће имало њен пријем у монаштво. То потврђује, између осталог, и случај извесне Фетјушке осуђене на смрт због убиство мужа, коме је косом одсекла главу. Чворовић 2013, 349.

42 Томсинов 2011, 252.

43 Иако у Саборном уложенију цара Алексеја Михајловича од 1649. године убиство жене није било регулисано као посебан облик кривичног дела убиства, жена се с друге стране појављује у овој кодификацији као искључиви починилац појединих квалификованих облика истог кривичног дела, као што је убиство мужа и чедоморство. Чворовић 2013, 348-351; Чворовић 20186, 486-487.

44 Владимирский-Буданов 1915, 447; Чворовић 2013, 350-351.

45 Сергеевич 1910, 423.

46 Соборное уложение 1649 года 1987, 388.

47 Исто.

48 Чворовић 2018в, 78.

49 Колосовский $1857,196$.

50 Липшиц 1965, 72, 188.

51 Статут велікага літоўскага 1588, XI, 6, 1989, 428. 
власти, тако и од јавности, као нехатно прекорачење дисциплинске власти мужа, које је у пракси неретко било извршавано у стању смањене урачинљивости. ${ }^{52}$

\section{Телесне повреде}

Као и у свим словенским и германским leges barbarorum, и у Руској правди казуистично се регулишу бројни облици кривичног дела наношења телесних повреда, али се при томе не прави разлику по основу пола починиоца и оштећеног. ${ }^{53}$ Из црквеног Устава кнеза Јарослава се, међутим, види да је онај ко би само ошамарио по лицу слободну туђу жену кажњаван новчаном казном од 6 гривни која се уплаћивала епископу. Уз то, учинилац је био дужан да таквој жени, будући да јој је повредио част, плати обештећење „по закону“ (Аже муж бьеть чужю жену, за сором ей по закону, а епископу 6 гривен, чл. 28). ${ }^{54}$ Релативно висока казна од 6 гривни за шамар нанет жени показује да се у руском праву физички напад на жену строже кажњавао од физичког напада на мушкарца. Наиме, према Широј редакцији Руске правде новчана казна (продажа) од 3 гривне била је предвиђена за одсецање једног прста, као и за ударац мачем који би направио рану, али не би смртно угрозио оштећеног. ${ }^{55}$ Висина пеналног обештећења код телесних повреда нанетих жени одређивала се, према тврдњи Н. Пушкареве, од времена Псковске судне грамоте проценом здравственог стања оштећене. ${ }^{56}$ Према чл. 26. Судебника од 1550. године висину пеналног обештећења код телесних повреда утврђивао је суд у сваком појединачном случају тако што је узимао у обзир тежину повреде и друштвени статус повређеног: А за увечие указывати крестианину, посмотря по увечию и по бесчестию; и всем указывати за увечие, посмотря по человеку и по увечию. 57

До доношења Саборног уложенија од 1649. године односи унутар породице били су регулисани Крмчијом и за њих је био надлежан црквени суд. Муж је за телесне повреде које би нанео супрузи кажњаван епитимијом, која је према појединим изворима трајала шест година, док је жена у таквој ситуацији стицала право на развод брака, што је била својеврсна грађанскоправна санкција. ${ }^{58}$ Једна судска пресуда из 1640 . године у којој је, поред осталог, стајало - смирити своју жену сходно њеној кривици и људски, али не осакаћивањем - изражавала је, према мишљењу Владимирског-Буданова, ондашње обичајноправно схватање о томе где престаје легална дисциплинска власт мужа, а почиње кривична одговорност за телесне повреде. ${ }^{59} \mathrm{y}$,Домостроју“ се мужу саветује да стално подучава жену „корисним саветима“ и да је „воли и награђује“ уколико се понаша онако

52 Чворовић 2013, 350-351.

53 Николић 2000, 204; Пушкарева 1989, 146. И поједини германски leges barbarorum, као што су примера ради Lex Salica и Lex Ripuaria, не наводе посебно жене као жртве појединих облика кривичног дела телесних повреда. Bartulović, Erent-Sunko, Pezelj 2018, 1105-1106. Lex Alamannorum регулише бројне различите облике кривичног дела телесних повреда независно од пола жртве (поједини видови телесних повреда могли су бити нанети само мушкарцу, као што је откидање полног органа или кастрирање). Међутим, овај германски lex barbarorum садржи посебну одредбу општег карактера у којој се прецизира да су све компензације које су придвиђене код телесних повреда довоструко веће када је оштећена жена (Haec omnia conpositio quod ad viris iudicavimus, ad feminis eorum omnia dupliciter conponatur, чл. 68). Данилова 1969, 147.

54 Владимирский-Буданов 1876, 205.

55 Памятники права Киевского государства X-XII вв.1952, 110.

56 Пушкарева 1989, 146.

57 Российское законодательство 1984, 101; Колосовский 1857, 109.

58 Пушкарева 1989, 146.

59 Владимирский-Буданов 1915, 446. 
како је предвиђено „Домостројем,“ али ако се она „не држи поуке и ништа не испуњава“ онда је „муж дужан“ да је „казни““ и „уразуми,“ али „без гнева““60 Писац „Домостроја“ не каже ништа о томе како муж сме кажњавати жену, а поједини истраживачи ${ }^{61}$ су пасус о кажњавању жене повезивали са следећим пасусом у коме се говори о томе како муж и жена смеју кажњавати непослушне слуге. За слуге се саветује да се ради избегавања већих невоља не туку у гневу гвозденим или дрвеним предметима, нити да им се наносе ране, нити да се бију по лицу, већ само да се истуку прутевима, а ако је „кривица велика“ онда по голој задњици. ${ }^{62}$ Писац ,Домостроја“ је у сваком случају морао имати у виду бројне случајеве злоупотребе очинске и господарске власти, чим је сматрао да су неопходне поуке о прихватљивој мери телесног кажњавања. ${ }^{63}$

Према Уставу кнеза Јарослава (чл. 30. Кратке групе Источно-руске редакције), који је улазио у састав руске редакције Крмчије, част и телесни интегритет мајке и оца уживали су подједнаку заштиту од физичког злостављања њихове деце. Дете које би физички напало једног од родитеља било би осуђено на новчану казну у корист епископа и уз то би било кумулативно кажњено још једном световном казном која се крила иза израза волостельская казнь. Правни историчар В. И. Сергејевич (Василий Иванович Сергеевич) је претпостављао да волостельская казнь „може бити баш она казна коју су епископи препоручивали још Владимиру, тј. смртна казна.“ За кажњавање детета смрћу, не само када убије родитеља, већ и када му нанесу телесну повреду могао се наћи основ у Крмчији, у којој је из Мојсијевог законодавства преузето правило: Аще человек злоречит отиу своему или матери своей, смертию да умрет. ${ }^{64}$ Први пут руска држава

60 Домострой 2014, 83.

61 Дубакин 1880, 76-77; Левин 2006, 325; Данилевский 1998, 264.

62 Навдена два пасуса Домостроја, који су често били предмет искривљених тумачења, гласе: „За всем тем и за всем порядком следить должна жена да наставлять слуг, и добрим и лихом, а коли не понимают слова - и ударить не грех. А увидит муж, что непорядок у жены и у слуг, или не так все, как в книге этой изложено, сумел бы свою жену вразумлять да учить полезным советом; если внемлет и так все и делает, - любить и жаловать, но если жена науке этой, наставлению его не последует и того всего не исполняет, о чем в этой книге сказано, и сама ничего из сказанного не знает и слуг не учит, должен муж жену свою наказывать, наедине вразумлять ее страхом, а наказав, простить, и приласкать, и любовью наставить и рассуждением, но при этом мужу на жену не гневаться, а жене на мужа - жить им всегда в любви и в согласии.

А слуг также, по вине смотря и по делу, учить, и наказывать, и рани возлагать, а наказав, пожалеть. Госпоже же пристало за слуг просить во всем мужа рассудительно, тогда у слуг и надежда есть. Но если слову жены, или сына, или дочери слуга не внимает, наставление отвергает, не слушает и не боится их, не делает того, чему муж, или отец и мать его учат, то плетю постегать, по вине смотря, да не перед людьми, наедине поучить, поучив же, поговори с ним и пожалей, но никогда не гневаться вам друг на друга. Ни за какую вину ни по уху, ни по лицу не бить, не кулаком под сердце, ни пинком, ни посохом не колоть, ничем железным и дервянным не бить. Когда в сердцах или с кручины так бьют, многие беды от того случаются: слепота и глухота; и руку, и ногу, и палец вывихнут; наступают головные боли и боль зубная, а у беременых женщин и дети в утробе повреждаются. В наказание бить плетю - и разумно, и больно, и страшно, и здорово. Если вина велика, за ослушание и небрежение - рубашку снять и, за руки держа, плетью высечь, сколько нужно, по вине смотря, да побив, поговорить по-доброму. И сделать все так, чтобю и гнева не было, и люди бы о том не слыхали, и жалобы бы о том не было. Да никогда бы не было брани, и побоев, и гнева на слуг по оговору из-за вражды без должного розыску.“Домострой 2014, 83-84.

63 Батинање, као мера дисциплинског кажњавања искушеника и монаха, није било реткост у руским манастирима у XVI и XVII веку, па су против такве праксе неретко оштро протествовали поједини архијереји Руске цркве. Попов 1904, 81-85.

64 Сергеевич 1910, 422. 
интервенише у породичне односе појединим прописима Саборног уложенија од 1649. године, па се у њему, између осталог, прети телесном казном беспоштедног јавног бичевања (бить кнутом же нещдно) сину или кћерки уколико туку своје родитеље, опљачкају их или их једноставно не поштују. Следствено, телесни интегритет и част мајке уживали су према кодификацији цара Алексеја Михајловича (Алексей Михайлович) подједнаку кривичноправну заштиту као телесни интегритет и част оца. ${ }^{65}$

\section{Силовање}

Иако садржи посебан пропис о убиству жене, у Руској правди нема помена силовања или другог кривичног дела којим се од физичких напада штити не само здравље, већ и част жене (dehouestatio mulieris). ${ }^{66}$ Такви прописи су се уместо у Руској правди у најранијем периоду развитка руског права налазили у црквеним уставима великог кнеза Владимира и његовог сина Јарослава, пошто су управо овим уставима руски кнежеви предали у надлежност црквеног суда сексуалне деликте и деликте против јавног морала. ${ }^{67}$ Тако се Уставом кнеза Владимира гарантује да „кнез и бојари и њихове судије не суде,“" поред осталог, ни пошибанье, које је још познати руски каноничар А. С. Павлов (Алексей Степанович Павлов) протумачио као силовање. ${ }^{68}$ Црквени Устав кнеза Владимира не одређује, међутим, казну за силовање, већ оставља црквеним судовима да примене одговарајуће прописе Крмчије.

65 Стари руски законодавац је посебно водио рачуна о томе да се интервенција државног суда у осетљиве прородичне односе не остварује $e x$ officio, већ искључиво на основу иницијативе чланова саме породице. Тако су према Саборном уложенију деца могла бити кривично гоњена за злостављање родитеља само на основу пријаве оца или мајке ( $и$ в том на них отеи или мати учнут государю бити челом). Томсинов 2011, 251; Соборное уложение 1649 года 1987, 384-385.

66 Владимирски-Буданов с правом оцењује силовање као деликт са сложеним заштитним објектом, што га истовремено чини кривичним делом против здравља, части и морала. ВладимирскийБуданов 1915, 325 .

67 Владимирский-Буданов 1915, 324-325; Пушкарева 2012, 9. Још је Владимирски-Буданов закључио да то што „Руска правда уопште не помиње сексуалне деликте може да служи као доказ: а) да су црквени устави, по којима су кривична дела ове групе предата црквеном суду, стварно били израз ондашњег важећег права; б) да су се зборници Руске правде састављали ради практичне употребе у судовима и зато је у њима заобилажено све што се није могло применити пред световним судовима.“ Владимирский-Буданов 1876, 100.

68 Памятники права Киевского государства X-XII вв.1952, 245, 249; Попов 1904, 192; Словарь русского языка XI-XVII вв. 1992, 83, 84. Ив Левин, не консултујући релевантну руску литературу из 20. века, погрешно преводи израз пошибати из Устава кнеза Јарослава као превару. Левин 2006, 305. Иначе је вредност ове студије о сексуалном животу код православних Словена од X до XVIII века врло упитна, и поред тога што је ауторка користила бројне изворе. У њој се, већ на први поглед, уочавају не тако ретке материјалне грешке (Нпр. „Код православних Словена робиње су од сексуалног насиља највише штитили руски световни закони, а не црквени канони (!),“315), као и драстични примери неразумевања материје о којој ауторка пише (Нпр. „У покајним списима свештенику је саветовано да пропише строгу епитимију за мужа који присили своју жену да упражњава анални секс. Неке верзије овог прописа су намерно нејасне (!) и дозвољавају свештенику да се умеша кад год се жена пожали да ју је муж 'грешно силовао'(!),“ 331$)$. Уз то, студија Ив Левин врви од баналних генерализација и негативних стереотипа о православним Словенима (Нпр. „Средњовековни Словени су прихватили употребу насиља надређених над подређенима и онима који су прекршили закон; ово је природни поредак грешног света. У овим друштвима, као и у било ком друштву које одобрава насиље и подређеност жена мушкарцима обавезно долази до силовања,“ 334). 
Устав Владимировог сина, кнеза Јарослава, самостално прописује казну за силовање. У обе редакције Јарослављевог црквеног Устава, Краткој и Широј, наведени пропис се налази у члану 2. Учинилац силовања се кажњавао новчаном казном, чија је висина зависила од друштвеног статуса силоване жене. Новчана казна се уплаћивала епископу, али је истовремено учинилац био дужан да оштећеној исплати обештећење у висини новчане казне. ${ }^{69}$ Обавезу плаћања обештећења силованој жени из Устава кнеза Јарослава Н. Л. Пушкарева је повезала, чини се с правом, са одредбом у старој Русији изузетно популарног Закона судњи људем, која прописује да „онај који силује невину девојку... буде продан, а његово имање нека се преда девојци“ (чл. 9; сл. и чл. 10). ${ }^{70}$ Арапски путописац и географ из XII века Абу-Хамид забележио је да се код Руса за „непоштовање угледне жене могла изрећи казна одузимања имовине.“71 Пошто је Византији била потпуно непозната јурисдикција црквеног суда у сфери сексуалних деликата, као и пракса налагања новчаних казни од стране црквеног суда, Шчапов (Ярослав Николаевич Щапов) је настанак овог и сличних прописа Јарослављевог Устава довео у везу са настојањем кнеза Јарослава и митрополита Илариона, првог Руса на престолу Кијевске митрополије, ${ }^{72}$ да из употребе потисну грчки Номоканон. И уз то, да телесне казне из византијских закона ${ }^{73}$ замене новчаним казнама, пошто је телесно кажњавање било неспојиво са покајно-дисциплинском улогом црквеног суда. ${ }^{74}$

Речи „и князь казнить“ на крају прописа о силовању из Устава кнеза Јарослава сугеришу да се силовање, речју Владимирског-Буданова, „сматрало не само грехом, него и злочином пред друштвом,“ који је кажњаван и од стране кнежевог суда, али тек после суђења пред црквеним судом (Аже кто пошибаеть боярскую дщерь или боярскую жену, за соромъ ей 5 гривенъ золота, а епископу 5 гривенъ золота; а меншихъ боярь гривна золота, а епископу гривна золота; а нарочитюх людей 3 рубли, а епископу 3 рубли; а простой чади 15 гривенъ, а епископу 15 гривены, и князь казнитъ). ${ }^{75}$ Чини се, међутим, да је такво укључивање световног суда у процесуирање силовања плод неке касније редакторске интервенције у основни текст Устава кнеза Јарослава, који се може довести у везу с процесом централизације власти московских великих кнежева у XIV и XV веку. ${ }^{76}$ Осим у погледу овог додатка пропис о силовању у обе редакције Устава, Краткој и Широј, спада у ред малобројних прописа које, речју Шчапова, „треба приписати архетипу Устава.“ То би значило да се у време настанка првобитног текста Устава кнеза Јарослава, у XI

69 Памятники права Киевского государства X-XII вв.1952, 259, 266, 277-278; Попов 1904, 192; Пушкарева 1989, 142.

70 Пушкарева 1989, 144-145. Одредба Закона судњи људем навдена према: Николић 2016, 69.

71 Пушкарева 1989, 144.

72 Чворовић 2020, 92.

73 У Еклоги се силовање удате жене (XVII, 32) и пунолетне неудате девојке (XVII, 30) кажњавало одсецањем носа, док се силовање малолетне девојке кажњавало одсецањем носа и новчаном казном у висини половине имовине учиниоца (XVII, 31). У Прохирону је казна за силовање неудате пунолетне девојке пооштрена, пошто се учиниоцу изрицала, поред казне одсецања носа, и новчана казна у висини трећине његове имовине (XXXIX, 66). Липшиц 195, 71; Laiou 1993, 122.

74 Щапов 1971, 75-77. До таквог прилагођавања византијске казнене политике код кривичног дела силовања већ је дошло у најстаријем словенском закону - Закону судњи љьдем, у коме је казна одсецања носа изостављена како за силовање пунолетне, тако и за силовање малолетне девојке. Истовремено је у оба случаја повећана имовинска казна из византијског права, јер се предвиђала продаја целокупне имовине учиниоца и предаја тако добијеног новца жртви. Николић 2016, 69, 82. 75 Владимирский-Буданов 1876, 202.

76 Щапов 1972, 238. 
или првој половини XII века, ${ }^{77}$ силовање у руском праву искључиво кажњавало новчаним казнама у корист црквеног суда и пеналним обештећењем у корист силоване жене. ${ }^{78}$

Да се силовање у периоду од XI до XIII века код Руса кажњавало управо онако како је прописивао чл. 2. Јарослављевог Устава, потврђује и пропис о силовању из Уговора Новгорода с Готландом и немачким градовима ${ }^{79}$ од 1189/99. године. Појаву такве инкриминације баш у овом међународном Уговору Пушкарева објашњава претходним немилим искуством становника Новгорода с Варјазима. Тако Нестор у „Повести минулих лета“ бележи догађај из времена владавине кнеза Јарослава (1016. године), када Новгородци иссекоше Варягы в Поромоне дворе који су били у служби кијевског кнеза Јарослава, између осталог и због силовања удатих новгородских жена (насилие денят на мужатых женах). ${ }^{80}$ Уговор Новгорода с немачким градовима предвиђао је да се онај који би силовао удату жену или девојку кажњавао виром од 40 гривни куна (чл. 7). Пошто се вира уплаћивала кнезу, Уговором се учинилац обавезивао да претученој жени или девојци

77 Исто, 239, 278.

78 Аутори који историју руске културе истражују са родног становишта, мада генерално оцењују као негативан утицај хришћанства на сексуалност Руса, признају да је Црква у средњовековној Русији сексуалне деликте искључиво кажњавала новчаним казнама, те да стога „у текстовима староруских извора XIV и XV века нема никаквих података о бесчастећим казнама за сексуалне деликте.“„Ужаси византијских правних кодекса, попут оног да 'прељубник буде бијен и ошишан и да му се нос уреже,' нису се примили на руској земљи,“"закључују исти аутори. Пушкарева 2012, 13. Силовање се кажњавало глобом и у српском средњовековном праву све до доношења Душановог законика. Тек од Душановог законика (чл. 53) за силовање су уведене телесне и смртна казна, с тим што је врста казне зависила од друштеног статуса учиниоца. Тарановски 1996, 447; Душанов законик 2010, 168; Соловјев 1980, 217-218. Замена у Душановом законику традиционалне новчане казне за силовање смртном и телесном казном морала је да доведе до промене стварно надлежног суда. Са основаношћу се може претпоставити да је пре доношења Законика, црквени суд био надлежан, као и у средњовековној Русији, да суди кривична дела против полног морала. Стога се појавила потреба да се у другом Законику од 1349. посебном одредбом члана 192. (Раковички рукопис) изричито потврди надлежност царског суда за силовање. Соловјев 1980, 329. Иако је промена у кажњавању силовања извршена под утицајем византијског права, Душан је у односу на византијски узор драстично пооштрио казне за силовање, што је, према А. Соловјеву, могло доћи под „утицајем западних правних система.“ Соловјев 1998, 488. Примера ради, у средњовековном енглеском праву јасно се уочава тенденција пооштравања казне за силовање. Са норманским освајањем традиционална казна за силовање из англосаксонског права - законска композиција, мења се у време Хенрија I у Leis Willelme казном кастрације, која је пре тога у Закону краља Алфреда једино била предвиђена код силовања које почини роб $(25,1)$. Занимљиво је објашњење којим чувени Бректон оправдава казну кастрације за силовање неудате девојке као најтежег облика кривичног дела силовања. Према Бректону кастрирање има, заправо, смисао симболичног талиона, јер је казна одсецања мушког полног органа пропорционална дефлорацији химена силоване невине девојке. Вестминстерски статути од 1275 . и 1285. године мењају казну кастрације смртном казном, мада је судска пракса, и пре и после тога, неретко одступала од законских прописа. Eska 2013, 154; Dunn 2013, 26, 78-79; Хрестоматия памятников феудального государства и права стран Европы 1961, 73. 79 За историју руског права XIII и XIV уговори које су поједини руски градови (Новгород, Смоленск, Полоцк) закључивали с немачким градовима (Ханзом, Готландом, Ригом) од великог су значаја већ због чињенице што су, речју Владимирског-Буданова, „њихове правне норме (у неким од њих веома бројне), за разлику од оних из уговора с Грцима, готово идентичне с руским правом (захваљујући културној блискости уговорних страна).“ Владимирский-Буданов 1915, 91-92. Према А. Н. Филипову истраживачи посебну пажњу треба да поклоне најранијим уговорима с Немцима, какав је пре свих Уговор Новгорода од 1189/99. године, јер „често дају занимљиве податке о питањима којих се Руска правда није дотицала.“ Филиппов 1907, 70.

80 Пушкарева 1989, 142. 
плати обештећење у висини новчане казне (вире) за ово дело (Оже пошибаеть мужеску жену любо дчьрь, то князю 40 гривн ветхъми кунами, а жене или мужьское дчери 40 гривн ветхыми кунами) ${ }^{81}$ То што је новчану компензацију „добијала лично повређена жена, а не њен муж или сродник,“ „разликовало је,“ по речима водећег руског специјалисте у области родних студија Наталије Пушкареве, „правни положај руских жена од положаја њихових европских савременица, пошто је код њих накнаду за напад на част жене увек добијао муж.“82 Пушкарева пренебрегава чињеницу да је и византијско право у Еклоги и Прохирону предвиђало за поједине облике силовања уплату новчане казне у корист оштећене жене. ${ }^{83}$

За разлику од Устава кнеза Јарослава, у Уговору Новгорода с немачким градовима вира за силовање уплаћивана је кнезу, а не епископу, што упућује на закључак да је овим Уговором за кривично дело силовања била установљена надлежност световног, а не црквеног суда. Из ове чињенице се, међутим, не може извући закључак да је у Новгороду генерално редукована надлежност црквеног суда у односу на обим надлежности гарантован црквеним уставима великих кнежева Владимира и Јарослава. Радило се о изузетку који је се тицао Немаца чији је правни положај у Новгороду био уређен овим двостраним међународним уговором и за које није могао бити надлежан суд православне Цркве, будући да су били римокатолици.

Имајући у виду пропис о силовању из Уговора Новгорода с немачким градовима од 1189/99. године, Владимирски-Буданов је изнео тезу да је код Руса у најранијем периоду државноправног развитка женска част уживала привилеговану кривичноправну заштиту у односу на част мушкарца. ${ }^{84}$ Наиме, у овом Уговору вира од 40 гривни куна, којом се кажњавало силовање, била је предвиђена још само за убиство обичног Руса или Немца, односно новгородског или немачког трговца (чл. 3). ${ }^{85}$ Уговори Смоленска са Ригом и Готландом, први из 1229. и други између 1230. и 1270. године, показују да је висина новчане казне и обештећења за силовање у руском праву у XIII веку по свој прилици варирала од полувире (5 гривни сребра што одговара 20 гривни куна) у првом Уговору Смоленска са Ригом и Готландом до потпуне вире (10 гривни сребра, односно 40 гривни куна) у другом Уговору (као и у Уговору Новгорода с немачким градовима од $1189 / 99) .86$

81 Памятники права феодально-раздробленной Руси XII-XV вв. 1953, 125, 129. Тачно прецизирање у Уговору Новгорода с немачким градовима не само износа вире, већ и износа обештећења, Владимирски-Буданов је доводио у везу с тим што се „у Руској правди увреда нанета жени није издвајала из општег појма увреде“. Владимирский-Буданов 1876, 91.

82 Пушкарева 1989, 145.

83 Липшиц 195, 71; Laiou 1993, 122. Уплата новчане казне у корист жене жртве силовања или отмице јавља се и у појединим германским leges barbarorum, као што је Визиготски закон (De raptu virginum vel viduarum, III, 3, 5, Si quicumque rapiat alienam sponsam: Si alienam sponsam quicumque rapuerit, de raptoris ipsius facultatibus medietatem puelle, alia vero medietatem sponso iubemus addici). Вестготская правда 2012, 300.

84 Владимирский-Буданов 1915, 320.

85 Памятники права феодально-раздробленной Руси XII-XV вв. 1953, 129. У Уговору је двострука вира од 80 гривни била предвиђена само за убиство дипломатског представника (чл. 2), таоца и свештеника (чл. 15). Владимирский-Буданов 1876, 90, 93.

86 За оцену стварне важности прописа о силовању из два уговора Смоленска са Ригом и Готландом од значаја су закључци које је о овим уговорима изнео угледни руски историчар Зимин. Он истиче како се други Уговор Смоленска са Ригом и Готландом, сачуван у руском оригиналу, „темељио на 'Правди' (први Уговору, прим. 3. Ч) кнеза Мстислава Давидовича (од 1229. г),“ док је први Уговор од 1229. „неспорно садржао норме руског права које су се примењивале у Смоленску почетком XIII века.“ Памятники права феодально-раздробленной Руси XII-XV вв. 1953, 55, 79-80. 
Представнице руске феминистичке историографије, Пушкарева, Белова (Анна Валерьевна Белова) и Мицок (Натальа Александровна Мицок), признају да се силовање у раном руском праву кажњавало неуобичајено високим новчаним казнама, доводећи такве норме у везу са хришћанском етиком која је силовање сматрала ,једним од најозбиљнијих моралних преступа.“ Исте ауторке истичу како се под утицајем родног стереотипа о високој вредности женске невиности нарочито строго третирало силовање невине девојке. ${ }^{87} \mathrm{C}$ тим у вези, пропис о силовању из Уговора Смоленска са Ригом и Готландом од 1229. (чл. 12), као и пропис о силовању другог Уговора од 1230-1270. (чл. 23), заиста праве разлику у висини новчане казне с обзиром на раније владање оштећене. Уколико се пре силовања „ништа није чуло о њеном неморалу“ ( тада је оштећена жена добијала петоструко већу вредност обештећења од вредности коју добије силована жена „сумњивог морала“ (Аще которыи Немчичь учинит насилье над волною женою [в] Смоленьске, а дотле не сльишати было блядне ее, 5 гривен серебра за сором. Будет ли дотле бляла, гривна серебра за сором, чл. 12). ${ }^{88}$

Наведени прописи о силовању из Устава кнеза Јарослава и међународних уговора руских градова пружали су кривичноправну заштиту од силовања слободној удатој жени или девојци, али је у раном руском праву заштиту од силовања уживала и робиња (холопка), мада је била објект, а не субјект права. ${ }^{89}$ Најранији сачувани пропис који инкриминише силовање робиње налази се у Уговору Новгорода с немачким градовима од 1189/99: „Ко изврши насиље над робињом (поврежеть насильемь), али је не обесчасти, тада за увреду гривна (1 гривна куна, односно $1 / 4$ гривне сребра); ${ }^{90}$ ако је ипак обесчасти (соромить) да је слободна (чл. 14).“91 Израз поврежеть насильемь Владимирски-Буданов и Зимин тумачили су као покушај силовања. ${ }^{92}$ Уговори Смоленска са Ригом и Готландом такође предвиђају правну заштиту робиње од силовања, али изостављају меру ослобађања силоване робиње. ${ }^{93}$ На овим руским прописима о силовању робиње видљив је очигледан утицај византијске Еклоге, који је у XII и XIII веку могао доћи посредством две одредбе (чл. 4. и 5) о силовању робиње из популарне ране словенске компилације Закона судњи људем, која је била на гласу у средњовековној Русији. ${ }^{94}$

87 Пушкарева, Белова, Мицок 2020. Према византијској Еклоги (чл. 29) свака полна веза са невином девојком остварена „уз њену сагласност, али без знања родитеља“ квалификовала се као кривично дело блуда, које се кажњавало тако што је осуђеном блуднику одсецан нос и уз то је био дужан да оштећеној девојци плати високо пенално обештећење, а ако је „сасвим бедан и сиромашан“ кажњаван је кумулативно батинањем, срамотном казном шишања и прогонством. Липшиц 195, 71; Чворовић 2014, 181-182.

88 Памятники права феодально-раздробленной Руси XII-XV вв. 1953, 62, 75. Проституција у Русији je, по свој прилици, пре реформаторске владавине Петра Великог била спорадична појава, неупоредиво мање раширена него у другим европским земљама. Занимљиво је да најстарије сачувано сведочанства о борделу и организованој проституцији у Русији потиче из периода 16111617. и везано је за Велики Новгород и то у периоду када је град био под шведском контролом, пре Столбовског мира од 1617. године. Ролдугина 2021.

89 Владимирский-Буданов 1876, 93.

90 Пушкарева 1989, 143.

91 Исто.

92 Исто; Памятники права феодально-раздробленной Руси XII-XV вв. 1953, 130.

93 Памятники права феодально-раздробленной Руси XII-XV вв. 1953, 62, 75.

94 Чворовић 2014, 184-185; Милов 1998, 113; Калачов 1850, 19; Пушкарева 1989, 143. Према Закону судњи људем блудник који блудничи са сопственом робињом кажњаван је црквеном казном седмогодишњом епитимијом, док је робиња одузимана и продавана, а новац добијен од такве продаје делио се сиротињи. Блуд са туђом робињом повлачио је за блудника високу новчану казну у корист њеног власника и седмогодишњу епитимију. Николић 2016, 67-68. 
Употреба израза насилие за силовање у раним руским правним (Уговор Смоленска с немачким градовима од 1226) и литерарним изворима (Летопис од 1076), ${ }^{95}$ била би према кључном лингвистичком аргументу радикалног феминизма доказ да се силовање у руском средњовековном праву врло рано третирало као деликт насиља, а не као деликт против имовинских права оца или мужа. ${ }^{96}$

Каснији правни споменици московске епохе углавном не садрже прописе о силовању. Тако се међу малобројним кривичним делима која су инкриминисана у претежно процесноправним Судебницима Ивана III (Иван III Васильевич) и Ивана IV (Иван IV Васильевич) не налази силовање, док је у обимном Саборном уложенију цара Алексеја Михајловича био регулисан само један квалификовани облик овог кривичног дела. Реч је о силовању које изврше војна лица у време прекоманде на нову дужност или приликом одласка с војног похода кући (А будет кто ратные люди, едучи на государеву службу, или з государевы службы по домом, учнут... женъскому полу насильство). Силовања су се догађала баш у том периоду зато што су војници, по речима законодавца, „искварени пљачком на непријатељској територији или, напротив, озловољени неуспесима и осиромашени у дугим походима без резултата или боравком у разореним земљама, потпуно били распуштени и неспремни да се повинују било каквој дисциплини. “97 Поред силовања у чл. 30. VII главе Саборног уложенија регулисани су и други деликти које су војници могли да изврше над цивилним становништвом сопствене државе, као што су убиство и грабеж (јавно отимање туђих покретних ствари). При томе је силовање по тежини изједначено са убиством, пошто су оба деликта ако их изврше војна лица кажњавана смртном казном, док је грабеж кажњаван двоструком накнадом штете. ${ }^{98}$

У циљу сузбиња неморала у друштву и спречавања злоупотреба власти господара над робињом (холопком), Саборним уложенијем се гарантује холопки, како удатој тако и неудатој, право на тужбу против сопственог господара уколико је с њим имала незаконити сексуални однос, а из тог односа је рођено дете. При томе се холопка непосредно обраћала надлежном државном органу, што говори о извесној процесноправној способности холопке. Потом би предмет био уступљен црквеним судовима, у Москви патријарховом, а у унутрашњости суду надлежног епископа. Главно доказно

95 Словарь русского языка XI-XVII вв. 1983, 244-245

96 И у Душановом законику израз којим се описује силовање оузме по силь упућује на закључак да је и у српском средњовековном праву ово кривично дело схватано као деликт насиља. Ив Левин истиче да „савремени социолози сматрају да је силовање првенствено чин агресије према женама а не понашање које призилази из сексуалне жеље“ и потом закључује, додуше без неког нарочитог образложења, како „средњовековни Словени су дошли до истог закључка, али на основу другачијих претпоставки.“ Левин 2006, 292. Још је Сузана Браунмилер истакла кључну тезу радикалних феминисткиња, према којој силовање у историји права почиње да се инкриминишао као имовински деликт, тј. као напад на својину мушкарца од стране другог мушкарца. Brownmiller 1993, 18. Овакав поглед на силовање био је својствен старом веку, али се задржао и у световном праву западних средњовековних држава. То се огледало, између осталог, и у употреби латинског израза за пленидбу имовине и људи raptus (Divković 1980, 889) као заједничког термина за силовање и отмицу жена у енглеском праву после норманског освајања, а под утицајем чувене Грацијанове компилације Decretum. Таква употреба семантички вишезначног израза raptus допринела је, према Каролин Дан, да се у средњовековној Енглеској учврсти поглед на жену као имовину, коју је могуће присвојити и отети. Dunn 2013, 28, 47, 51, 193. Други аутори истичу, насупрот томе, како су хришћанска Црква и њени каноничари, почев од позног XI века, дали кључни допринос да се силовање у западноевропским правима почне третирати као кривично дело против жене, а не као деликт против имовине оца или мужа. Pistono 1989, 41.

97 Томсинов 2011, 74; Соборное уложение 1649 года 1987, 171.

98 Соборное уложение 1649 года 1987, 172. 
средство у поступку било је саслушање духовника холопке и духовника господара ( $A$ кто учнет у себя в дому делати беззаконие с рабою з жонкою, или з девкою, и приживет с нею детей, и в том на него та раба учнет государю бити челом, и таких жонок и девок, и на кого они учнут государю бити челом, отсылати на Москве на Патриарш двор к патриаршим приказным людем, в городех к митрополичьим $и \kappa$ архиепископлим приказным же людем.. , 80, ХX).${ }^{99}$ Случајеви осуде бојарског сина Нехорошка Семичева из 1628. и столника (стольник) Количева из 1633. године због блуда са својим холопкама, показују да је Саборно уложеније само потврдило холопкама оно право које су у Московском царству уживале и пре 1649. године. У наведеним случајевима осуђени су послати у манастире да обављају физичке послове. ${ }^{100}$

Одсуство прописа о силовању из руских правних споменика који су донети у периоду од XV до XVII века упућује на закључак да су се у овом периоду на деликт силовања примењивали прописи руске редакције Крмчије. ${ }^{101}$ Претпоставка о примени Крмчије се чини нарочито оправданом ако се узме у обзир теза А. Попова (Ардалион Попов) да су све до краја XVII века и почетка реформи Петра Великог црквени судови судили за силовање. ${ }^{102}$

Судска пракса из XVII века показује да су судови за силовање најчешће изрицали комбинацију новчане казне у корист оштећене и временски орочени боравак учиниоца у неком од манастира. ${ }^{103}$ Својеврсни конзервативизам правног поретка Московске Русије изражавао се између осталог и у задржавању новчане казне за силовање, као традиционалног словенског и германског начина кажњавања овог деликта у раном средњем веку, и у XVI и XVII веку када се у већини европских права прописују бруталне казне за силовање, најчешће мутилација и прогонство. ${ }^{104}$ Додуше, Павле Алепски, који је боравио у Московском царству педесетих година XVII века, забележио је како „они (Руси) кажњавају смрћу без милости и опроста, четири злочина: издају, убиство, светогрђе и одузимање невиности девици без њене сагласности."105 То би значило да је за извесне облике силовања ипак био надлежан државни суд (вероватно после одлуке црквеног суда), пошто црквени суд није могао да изриче смртну казну. Поједини извори сведоче да су државни судови у другој половини XVII века судили за силовање и када је изрицана блажа казна од смртне. Тако је у једном случају из осамдесетих година XVII века суд Бојарске думе осудио за силовање девојке Маврутке Венцилејеве извесног Степана Коробина. Он је кажњен батинањем и прогонством у Соловјецки манастир, уз обавезу да жртви плати износ од 500 рубаља, док су саучесници, мушкарци и жене, подвргнути батинама, а потом су са својим породицама прогнани у Сибир. ${ }^{106}$ Из једног другог случаја види се да је новчана казна одређивана у висини $1 / 3$ имовине учиниоца, ${ }^{107}$ што је заправо била византијска казна из Прохирона, који је под именом „Закон градски“ улазио у састав руске штампане тзв. Јосифовске Крмчије. ${ }^{108} \mathrm{C}$ тим у вези, увек треба имати у виду да средњовековне судије, било да је реч о црквеним или световним судијама, нису биле везане, не само у Русији, већ и у Византији, начелом легалитета кривичног дела

99 Томсинов 2011, 221; Российское законодательство 1985, 402.

100 Соборное уложение 1649 года 1987, 343,

101 Калачов 1850, 22.

102 Попов 1904, 193.

103 Исто.

104 Исто, 433.

105 Попов 1904, 194.

106 Walker 2013, 439; Романов 2021.

107 Walker 2013, 439.

108 Laiou 1993, 122; Чворовић 2020, 87; Калачов 1850, 21, 114. 
и казне на начин на који је везан данашњи судија. ${ }^{109}$ Када је у питању кажњавање силовања за Московску Русију важи, по свему судећи, оно што је Ангелики Лају (Angeliki Laiou) закључила у погледу Византије: судије нису примењивале закон од речи до речи, али су пеналне накнаде штете увек плаћане силованој жени. ${ }^{110}$ Код кривичног дела силовања се у другој половини XVII века уочава тенденција преласка овог деликта из надлежности црквеног у надлежност световног суда, чиме је најављена Петрова епоха секуларизације права и јачања државе.

\section{Отмица}

Као и код свих словенских и германских племена, тако су и код Руса у предхришћанско доба биле честе отмице девојака као начин закључења брака. И сам кнез Владимир се пре крштења оженио полоцком принцезом Рогнедом, тако што ју је отео против њене воље, освојивши са дружином град Полоцк у коме је принцеза живела. 111 Отмице су, иначе, најчешће извршаване уз помоћ саучесника. ${ }^{12}$ Било је и отмица које су организоване у договору с невестом, а против воље њених родитеља, нарочито током појединих паганских празника. ${ }^{113}$

Ако су два века после Владимировог крштења црквена венчања била према сведочењу кијевског митрополита Јована II права реткост ван бојарских и кнежевских кругова (не бывает на простых людех благословение и венчание, но боляром токмо [и] князем венчатися), ${ }^{114}$ онда су се бракови код обичног света вероватно закључивали у једној од три форме које су биле наслеђене из предхришћанског доба: отмицом невесте, куповином невесте или договором о миразу који се давао уз невесту. ${ }^{115}$ Црква се борила против паганских обичаја отмице и куповине невесте, јер су ови обичаји порицали слободну вољу жене и потирали њену личност. ${ }^{116}$ Речју В. Шуљгина (Виталий Яковлевич Шульгин), ,узмите све најстарије црквено-судске изворе и видећете у њима отмицу као један од основних паганских обичаја који је хришћанска Црква тежила да искорени."117

Да је отмица невести била раширена појава и да се Црква жестоко борила против ове појаве види се из одредби црквеног Устава кнеза Јарослава. Отмица девојке (умчить - силом отети девојку) у Уставу кнеза Јарослава изједначена је у погледу казне са силовањем, пошто су за оба деликта биле прописане новчане казне скоро исте висине, а у зависности од друштевног статуса оштећене девојке (Аще кто умчить девку или понасилить, аще боярьская дщи, будеть за сором еи 5 гривен золота, а митрполиту 5 гривен золота; аще будеть мениих бояр, еи гривна золота, а митрополиту гривна золота; аще добрыих людеи будеть, две гривне серебра за сором, а митрополиту рубль,

109 Вершинин 2019, 239 и даље; Чворовић 2013, 30.

110 Laiou 1993, 196.

111 Ярмонова 2014, 26.

112 Исто, 24. У Византији је постојање саучесника узимано као доказ да је отмица извршена без сагласности девојке. Laiou 1993, 204.

113 Пушкарева 2011, 12-13; Ярмонова 2013, 101.

114 Памятники древне-русскаго каноническаго права 1908, 18.

115 Абрашкевич 1904, 474-475. Занимљиво је да је према Закону Ману брак закључен у форми куповине невесте (acypa) или отмице (ракшаса) девојке, чак и у форми отмице комбиноване са силовањем (пајшача), био резервисан само за две најниже касте - вајшије и шудре. Крашенинникова, Жидков 2008, 156.

116 Ярмонова 2013, 98.

117 Шульгин 1850, 10. Наведено према: Ярмонова 2014, 25. 
а на умычницех по 60 митрополиту, а князь их казнить). ${ }^{118}$ Иако је у пракси свакако било и отмица које су организоване с пристанком девојке чији су се родитељи противили њеном браку с младожењом отмичарем, у руском средњовековном праву казна за отмицу није зависила од тога да ли је отмици претходила сагласност девојке, као што је то било, примера ради, у пољском средњовековном праву. ${ }^{119}$ С тим у вези, у руском средњовековном праву није постављано ни питање евентуалне кривичне одговорности девојке која је дала сагласност за отмицу. По томе руско право следи доминантни ток византијског законодавства, који је започет Јустинијановим Едиктом о отмици из 533. године. Према овом Едикту сагласнот девојке није утицала на ублажавање смртне казне прописане за отмичара, нити је, с друге стране, доводила до кажњавања девојке. ${ }^{120}$

Пошто је у средњовековној Русији, за разлику од Византије, за отмицу био надлежан црквени суд, поставља се питање да ли је отмица, чак и када је извршена уз сагласност девојке, представљала трајну брачну сметњу за закључење црквеног брака, као што је то наређивао навдени Јустинијанов Едикт и што се потом, према Н. Милашу, утврдило у црквеној пракси. ${ }^{121}$ Ако судимо на основу Канонских одговора кијевског митрполита Јована II с краја ХІІ века, онда се чини да је Црква, барем у Кијевској Русији, сходно 22. и 30. канону Св. Василија Великог снисходила паровима који су закључили брак служећи се отмицом, под условом да су накнадно обезбедили родитељски пристанак и да су обавили црквено венчање. Наиме, митрополит Јована II је налагао свештеницима да оне који живе невенчано (бе[з] благословенья счетаются) треба „поучавати не једном, ни два пута, већ (сваког) различито, све докле год не познају и схвате истину и добру се врате,“"а да их треба одлучити (excommunicatio maior) од Цркве (чюжа имети от сборныля церкви) тек ако покажу упорност у греху (своея злобы не останучеся). ${ }^{122}$ Блажа правила о отмици изведеној уз сагласност девојке Св. Василија Великог била су очигледно прикладнија за мисију Цркве међу руским неофитима од строжих правила 27. канона Четвртог васељенског (27) и 92. канона Трулског сабора, према којима се брак закључен отмицом сматрао апсолутно ништавим. ${ }^{123}$

\section{Увреда части}

Руска правда не садржи пропис који би искључиво штитио част жене од реалних и вербалних увреда другог лица. ${ }^{24}$ За разлику од части мушкарца која ужива заштиту од

118 Памятники права Киевского государства Х-ХІІ вв. 1952, 265-266, 277; Попов 1904, 168.

119 Пушкарева 1989, 145; Ярмонова 2013, 101.

120 Laiou 1993, 142-143. У византијском законодавству је постојао и другачији начин регулисања кривичног дела отмице, али је он, по свему судећи, био другоразредан по свом утицају. Дошао је најпре до изражаја у Константиновом закону о отмици из 336. године, који за отмицу извршену уз сагласност девојке предвиђао не само смртну казну за отмичара (Damnatio ad bestias), већ је и девојку која је дала сагласност за отмицу лишавао права наслеђивања родитеља. Кривичну одговорност девојке која је дала сагласност за отмицу после Констатиновог закона предвидела је још само једна кратка Новела цара Андроника II од 1306. године, према којој се таква девојка кажњавала срамотном казном шишања и губитком части, док се мушкарац отмичар кажњавао новчаном казном у корист царске касе у висини трећине његове имовине. Laiou 1993, 141, 143.

121 Laiou 1993, 142-143; Милаш 2004а, 390.

122 Памятники древне-русскаго каноническаго права 1908, 7-8

123 Милаш 2004б, 379-380, 389-390; Милаш 2004a, 388.

124 Руска правда само на први поглед не инкриминише радње које су усмерене искључиво на повреду части, јер се код неких видова напада на тело човека не штити телесни интегритет и здравље, већ част и достојанство нападнутог лица. Тако се напад предметима који нису подобни да 
најранијих времена и која се у патријархално-војничком друштву Кијевске Русије углавном сводила на спољну димензију јавног угледа повезаног са друштвеним рангом и службеним положајем једног лица, почетак правне заштите женске части везан је за деловање хришћанске Цркве у старој Русији. Најпре је Уставом кнеза Владимира (чл. 7) црквеним судовима припала надлежност да суде за вербалне увреде (уреканье). Под утицајем хришћанског учења „част више не означава само спољно поштовање и уважавање, већ и унутрашње достојанство“ која има свака боголика личност независно од њеног социјалног положаја или пола. Тако у појму части морални елемент почиње да претеже над социјалним, иако га током средњег века никада неће у потпуности потиснути. Морално одређење части доводи до тога да се бесчестье као последица реалног или вербалног напада на част једног лица почиње повезивати са срамом и стидом. ${ }^{125}$

Имајући у виду утицај хришћанског погледа на свет на редефинисање појма части, није случајно да се најранији прописи о заштити женске части налазе управо у црквеном Уставу кнеза Јарослава. „Ако неко назове туђу жену курвом“ („Аже кто зоветь чюжу жену блядью“), казниће се тако што ће оштећеној платити пенално обештећење и у истом износу новчану казну надлежном епископу. Висина обештећења и казне зависила је од друштвеног ранга оштећене, при чему Устав разликује жену великог бојара, потом жену малог бојара, жену грађанина и најзад жену сељака. Да је женска част уживала високи степен кривичноправне заштите од вербалних увреда види се по томе што је висина казне и обештећења за увреду части била иста или нешто мања од новчане казне и обештећења који су истим Уставом прописани за силовање жене истог друштвеног ранга. ${ }^{126}$ Пооштрена кривичноправна заштита части жене од вербалних увреда у руском средњовековном праву подсећа на исту такву заштиту женске части у германском раном средњовековном праву. ${ }^{127}$ Стога се и високе новчане казне у руском праву за вербалну увреду жене могу објаснити, као и у германском праву, прагматичном потребом да се жена сачува „од срамоте или клевете како не би доживјела друштвену изолацију,“ јер „она у таквом суровом окружењу не би могла живјети самостално, без средстава за живот и било какве заштите.“"128

Уговор Новгорода с немачким градовима од 1189/99. године садржи пропис којим се штитила част удате жене или девојке од реалне увреде (Оже съгренеть чюжее жене повои с головы или дщьри, явится простоволоса, 6 гривн старые за соромъ, чл.

нанесу озбиљне повреде, као што су чаша, рог или дршка од мача, кажњавао са 12 гривни, док се одсецање прста кажњавало са 3 гривне, а потезање исуканог мача без убода са 1 гривном. Разлог је што се сукоб мачевима није сматрао увредљивим, пошто је лице нападнуто исуканим мачем увек могло да одговори, док су напади чашом или дршком од мача пре свега увредљиви, јер таквим нападом се поручује да је нападнути „кукавица, с којим не приличи борба с мачевима.“ Садржај ових прописа јасно показује да се њима не штити част жене, пошто објект оваквих напада није могла бити жена, већ искључиво мушкарац и његов друштвени углед у једној доминантно патријархалној култури, каква је била култура ране средњовековне Русије. Николић 2000, 212; Омельченко 2008, 241.

125 Стефанович 2004, 86-87; Памятники права Киевского государства X-XII вв.1952, 238, 250.

126 Владимирский-Буданов 1876, 204; Памятники права Киевского государства X-XII вв.1952, 261, 269, 279; Пушкарева 1989, 145-146.

127 И у германском праву вербална увреда жене кажњавана је оштрије кажњавана од вербалне увреде мушкарца. Тако Lex Salica прописује да ће се мушкарац или жена који за слободну жену кажу да је блудница, а то не докажу, казнити са 45 солида (XXX, 3). Док ће се онај ко за неког мушкарца каже да је бестидник или штрокавко казнити са 3 солида (XXX, 1, 2). Николић, Ђорђевић $2011,60$.

128 Bartulović, Erent-Sunko, Pezelj 2018, 1112. 
8). ${ }^{129}$ Наиме, онај ко би с главе туђе жене скинуо украсну мараму (повязка) ${ }^{130}$ морао би да јој плати 6 гривни, јер ју је увредио остављајући је „гологлаву“ (явится простоволоса). ${ }^{131}$ Под утицајем Цркве и њеног учења о смерности и послушању ${ }^{132}$ код Руса се врло рано гологлавост удатих жена и девојака сматрала непристојном. ${ }^{133}$ Црква је изрицала епитимију и оном ко би туђој жени намерно испрљао одећу, што се такође сматрало увредом женске части. ${ }^{134}$ Пенално обештећење (головничество) од 6 гривни прописано за скидање женске мараме, било је у Уговору Новгорода с немачким градовима предвиђено још само за батине или повреде нанете мушкарцу оружјем или тољагом („Оже ударять мужа оружеемь, любо колом... “, чл. 5). ${ }^{135}$ При томе, обештећење од 6 гривни у Уговору Новгорода с немачким градовима није било ништа друго него просечно обештећење прописано у Руској правди за телесне повреде, пошто су у Правди за различите облике овог деликта предвиђена обештећења у висни од 3 до 12 гривни. ${ }^{136}$ Да je у Уговору Новгорода с немачким градовима женска част уживала привилеговани статус и већи степен правне заштите од мушке части види се по томе што се насилно цепање мушке одеће (чл. 6), које је такође имало својство реалне увреде, кажњавало плаћањем пеналног обештећења од 3 гривне. ${ }^{137}$

И у каснијим правним споменицима московске епохе, која је окончана с реформама Петра Великог, част жене је уживала појачану правну заштиту од реалних и вербалних увреда у односу на част мушкарца. Тако је према чл. 26. Судебника цара Ивана

129 Владимирский-Буданов 1876, 91; Памятники права феодально-раздробленной Руси XII-XV вв. $1953,126$.

130 Повязка или повой личила је на убрус, односно мали пешкир који је жена обавијала око главе, скривајући целокупну косу, а често је падао и преко рамена. Головные уборы на Руси 2010.

131 Владимирский-Буданов 1876, 91.

132 Апостол Павле поручује Коринћанима: „И свака жена која се гологлава моли Богу или пророкује, срамоти главу своју; јер је једно исто као и ошишана“ $(1$. Кор. 11,5$)$. Апостол Петар поучава хришћанке речима „ваше украшавање да не буде споља: у плетењу косе и у кићењу златом или у облачењу хаљина“ (1. Петр. 3,3$)$. Још је Тертулијан у свом спису De cultu feminarum сматрао фарбање и дотеривање косе непримереним за хришћанке. ,Зар да се трудимо око погибељи наше браће,“ пита Тертулијан хришћанке, упозоравајући их како се „извештаченим улепшавањем побуђује похота у њиховим срцима.“ „Ако нови закон Господњи налаже једнаку казну и за жељу и за бесрамно дело: да ли ви мислите да ће остати некажњен онај који је другом изазвао погибељ? Знајте да ви истински уништавате брата свог када своју лепоту показујете пред његовим очима, изазивајући тако у њему похотне жеље. Он је у души својој већ извршио оно што је безаконо пожелео и ви постајете за њега мач који га убија,“"поручује Тертулијан хришћанкама. Tertulliani 2003.

133 Негативан став старог руског друштва према женској гологлавости дошао је до изражаја у семантици синтагме опростоволоситься, која је изведена из речи коса (волосы). Синтагма опростоволоситься првобитно је означавала „посебан тип друштвено неприхватљивог женског понашања“ када жена „скине мараму и остане с непокривеном главом на местима где то жени није дозвољено. “ Ово правило понашања у савременом руском друштву изгубило је на значају када су у питању православне житељке Русије, изузев код уласка жена у храм. У међувремену се трансформисала и семантика речи опростоволоситься, која у савременом руском језику значи обрукати се или учинити велики пропуст, грешку, али је као својеврсни колективни аксиолошки архетип „сачувана негативна оцена садржана у првобитном значењу глагола опростоволоситься.“ Крейдлин, Аркадьев, Летучий 2020; Ильин 2014.

134 Пушкарева 1989, 145.

135 Владимирский-Буданов 1876, 91; Памятники права феодально-раздробленной Руси XII-XV вв. $1953,125,128$.

136 Владимирский-Буданов 1876, 91.

137 Исто. 
IV Васиљевича од 1550. године бесчестие 138 за увреду жене било двоструко веће од износа пеналног обештећења које се плаћало за реалну или вербалну увреду мушкарца истог друштвеног ранга (,,а женам их бесчестиа вдвое“). ${ }^{139}$ Такву традицију када је у питању кривичноправна заштита части жене наставља Саборно уложеније од 1649. године. Према чл. 99. Х главе Уложенија за вербалну увреду удате жене (A будет кто ни буди обесчестит непригожим словом чью жену...) плаћало се, као и у Судебнику од 1550 , бесчестие двоструко веће од бечестия које би се дуговало да је вербално увређен њен муж. За вербалну увреду нечије неудате кћери (дочь девку) учинилац је према Саборном уложенију морао да плати четвороструко већи износ од износа који би дуговао да је увредио њеног оца. ${ }^{140}$

\section{Закључак}

Аутори који су се бавили друштвеним и правним статусом жене у Кијевској и Московској Русији издвојили су три фактора који су пресудно утицала на положај жене у средњем веку: патријархални морал и обичајно право родовско-племенског друштва, христијанизацију и татарско (монголско) наслеђе.

Један број руских истраживача из периода 19. века усвојио је под утицајем европског просветитељства и либерализма тезу да се положај жене погорашао са христијанизацијом руског друштва, почев од краја $\mathrm{X}$ века. ${ }^{141}$ Тако су, примера ради, за Забелина (Иван Егорович Забелин) „источна византијска морална животна начела,“ која су међу Русима усвојена током средњег века, била главни кривац за „удаљавање жене из мушког друштва,“ “као и за својеврсно ,заточење женске личност,“ те трајни останак жене у правном статусу детета. ${ }^{142}$ Чувени историчар царске епохе С. М. Соловјев (Сергей Михайлович Соловьёв ) сматрао је да је за формирање друштвеног и правног статуса руске жене у средњем веку била пресудна епоха татарског ропства и потоњег уједињење Русије од XIII до XV века, када се руски народ, с једне стране, удаљава од других хришћанских народа, док се, с друге стране, руши стари племенско-родовски поредак, нарави огрубљују, а човек се навикава да се руководи инстинктом самоодржања. У таквим условима затворничество жена, нарочито из виших сталежа, „није настало услед византијског, татарског или неког другог утицаја, већ је оно,“ закључује Соловјев, „било последица разумљиве моралне економије народног организма."

С тим у вези, Д. Дубакин (Дмитрий Николаевич Дубакин) је јасно указао на улогу хришћанског аскетског идеала у формирању друштвеног и правног положаја жене у Московској Русији. Он износи тезу да је хришћанска „аскетска идеја, преузевши на себе задатак супротстављања моралној распуштености руског друштва, у потпуности испунила тај задатак.“ „Усмерена против свега телесног и чулног, она је (аскетска идеја, прим. 3. Ч) у очима руског друштва заиста умањила значај брака, породичног живота и пре свега значај жене, али је зато искоренила неморал и разврат, који су били уобичајена

138 У руском средњовековном праву бесчестие је био назив за деликт реалне или вербалне увреде части, али и за пенално обештећење које се плаћало оштећеном. Российское законодательство 1985 , 294, 296.

139 Российское законодательство 1984, 101, 138

140 Томсинов 2011, 92-93; Российское законодательство 1984, 296; Соборное уложение 1649 года 1987, 191.

141 Яговец 2009, 149.

142 Наведено према: Дубакин 1880, 5.

143 Исто, 4. 
појава у ондашњем руском друштву на стадијуму преласка из паганства у хришћанство.“ Дубакин је, ипак, сматрао најважнијим то што је у Московској Русији „аскетски идеал, који се испољавао, између осталог, у доминацији манастирског поретка у свим сферама живота, утицао на устројство и карактер породичног живота руског друштва, успостављајући јединство поретка и усклађених односа међу члановима породице.“ „У епохи у којој су се све области живота руског друштва одликовале управо одсуством било какве правилности, поретка и чврстог опредељења, успостављање било каквог поретка, као и било какве равнотеже односа унутар породице било је од непроцењивог значаја,“ закључује овај аутор. ${ }^{144}$ Израз таквог уподобљавања породичног и брачног живота у средњовековној Русији манастирском животу и поретку дошао је до изражаја у „Домостроју,“ главној лектири породичне економије, педагогије и морала у Московској Русији. ${ }^{145}$

Управо у таквом идејном и моралном оквиру обликовани су бројни кривичноправни прописи о заштити части, здравља и живота жене у средњовековним руским правним споменицима. Први кривични прописи о силовању и отмици жене који су донети у Кијевској Русији и који у погледу казне изједначавају силовање и отмицу жене са убиством, настали су под снажним утицајем Цркве, која се у том периоду борила против појединих остатака паганског морала у сфери сексуалности и брака. Оштрија казнена заштита части жене у односу на част мушкарца, која је зачета у праву Кијевске Русије, а потом је задржана и разрађена у правним зборницима Московске Русије, обликована је, пре свега, под утицајем хришћанског учења о греху и стиду. Наиме, сваки реални или вербални атак на част жене од стране непознатог мушкарца који није био њен муж или отац вређао је част породице и њеног старешине и истовремено је нарушавао хришћански морални поредак у коме су част и тело жене били неприкосновени. Црква је допринела да се част, здравље и живот жене индивидуализују као правна добра и кривичноправно штите независно од интереса породичне заједнице. Под утицајем високог хришћанског вредновања девствености, нарочито тешким се сматрао сваки вербални или реални напад на неудату девојку. Такав аскетски поредак ствари био је једини кадар да сачува руски народа под влашћу иноверног татарског освајача и да омогући обнову његове државне независности. Једном речју, идејни, али и практични разлози утицали су да жена у руском праву још пре вестернизације Петра Великог добије привилеговану кривичноправну заштиту у односу на мушкарца.

Иако жена у средњовековном руском праву није уживала привилеговану кривичноправну заштиту када напад на њено тело, част или живот изврши њен муж, под утицајем Цркве озбиљно је ублажена древна паганско-патријархална форма дисциплинске власти мужа над женом, о којој у оскудици извора посредну представу можемо да стекнемо увидом у древне обичаје који су се дуго задржали у средњовековном руском друштву. На положај и права жене унутар брака и породице у средњовековној Русији, нарочито у московској епохи, пресудно је по свему судећи утицао старозаветни патријархални модел породичног живота, док је правна заштита жене у јавном простору углавном била инспирисана новозаветном етиком, као и практичним разлозима заштите физички слабијег пола у условима тешког средњовековног живота. ${ }^{146}$

144 Исто, 90-91.

145 Колесов 2004.

146 Яговец 2009, 150. 


\section{Литература}

Абрашкевич, Михаил Михайлович (1904): Прелюбодеяние с точки зрения уголовнаго права, Одеса: Экономическая типография.

Антонић, Слободан (2011): Искушења радикалног феминизма, Београд: Службени гласник.

Белова, Анна Валерьевна, Мухина, Зинара Зиевна (2019): Наталья Львовна Пушкареёва - основоположница изучения женской и гендерной истории в отечественной историографии, у: Гендер в фокусе антропологии, этнографии семьи и сочиальной истории повседневности, Москва: Институт этнологии и антропологии РАН, 7-16.

Вестготская правда (2012): Вестготская правда (Книга приговоров). Латинский текст. Перевод. Исследование. Отв. ред. Ауров, Олег В, Марей, Александр В., Москва: Русский Фонд Содействия Образованию и Науке.

Вершинин, Константин Владимирович (2019): Мерило Праведное в истории древнерусской книжности и права, Москва, Санкт Петербург: Нестор-История.

Владимирский-Буданов, Михаил Флегонтович (1876): Хрестоматия по истории русскаго права, Выпуск первыци, Киев: Типография Императорскаго Университета Св. Владимира.

Владимирский-Буданов, Михаил Флегонтович (1915): Обзор истории русскаго $n р а в а$, Петроград, Киев: Издание книжнаго магазина Н. Я. Оглоблина.

Георгиевский, Эдуард Викторович (2010): Убийство в уголовном праве Древней Руси, Сибирский юридический весник бр 2 (49), 9-106.

Головные уборы на Руси (2010): Головные уборы на Руси, История костюма, Family-history.ru, https://family-history.ru/material/history/kostum/kostum_6.html, приступљено: 16. 7. 2021.

Греков, Борис Димитриевич (1940): Правда Русская - Учебное пособие, Москва, Ленинград: Издательство Академии наук СССР.

Данилевский, Игорь Николаевич (1998): Деревняя Русь глазами современников и потомков (IX-XII вв.), Москва: Аспент Пресс.

Данилова, Галина Михайловна (1969): Аламаннское и баварское общество VIII и начала IX в., Петрозаводск: Издательство Карелия

Домострой (2014): Домострой: как устроить свой быт богоугодно, а жизнь свято. Перевод на соврменный русскй и общая редакция Т. Н. Терещенко, Рекомендовано к публикации Издательским Советом РПЦ ИС 11-026-3026, Москва: Дарь.

Дубакин, Дмитрий Николаевич (1880): Влияние христианства на семейный быт русскаго общества в период до времени появления „Домостроя“", Христианское чтение, бр. 3-4, 311-361.

Душанов законик (2010): Душанов законик. Приредио Бубало, Ђорђе, Београд: Завод уџбенике, Службени гласник.

Ильин, Денис Николаевич (2014): Описание особенностей национального сознания посредством анализа исторических трансформаций лексической семантики, Современная когнитивная лингвистика, https://www.researchgate.net/publication/ 266025234_OPISANIE_OSOBENNOSTEJ_NACIONALNOGO_SOZNANIA_POSREDST VOM_ANALIZA_ISTORICESKIH_TRANSFORMACIJ_LEKSICESKOJ_SEMANTIKI, приступљено: 1. 08. 2021.

Калачов, Николай Васильевич (1850): О значении Кормчей в системе древняго русскаго права, Москва: Университетская типография. 
Карташёв, Антон Владимирович (1993), Очерки по истории русской цееркви, Москва: Терра.

Колесов, Владимир Викторович (2004): Древняя Русь: наследие в слове. Бытие и был, Санкт-Петербург: Филологический факультет Санкт-Петербургского государственного университета, https://libking.ru/books/sci-/sci-culture/1093728-vladimir-kolesovdrevnyaya-rus-nasledie-v-slove-bytie-i-byt.html, приступљено: 2. 8. 2021.

Колосовский, Павел Димитриевич (1857): Очерк историческаго развития преступления против жезни и здоровья, Москва: Типография Т. Т. Волкова.

Крашенинникова, Нина Александровна, Жидков, Олег Андреевич (2008): История государства и права зарубежных стран, В 2 томах, Том 1, Москва: Издательство Норма.

Крейдлин, Григорий Ефимович, Аркадьев, Петр Михайлович, Летучий, Александр Борисович (2020): Тело и телесность в естественном языке и языке жестов (2020): Язык и семиотика тела, т. 1, Москва: Новое литературное обозрение, https://books.google.rs/books?id=osflDwAAQBAJ\&pg=PR3-IA126\&lpg=PR3-

IA126\&dq=головные + уборы + В + древней + руси + простоволосая\&source=bl\&ots=Nnmtx08 p_F\&sig=ACfU3U0JKTwcpMERRDsp4mu_8HLCUSKJbw\&hl=sr\&sa=X\&ved=2ahUKEwi 6 Ym2p8nxAhW hv0HHQiSDs0Q6AEwEnoECA0QAw\#v=onepage\&q=головные\%20убо ры\%20в\%20древней\%20руси\%20простоволосая\&f=false , приступљено: 16. 07. 2021.

Ланге, Николай Иванович (1860): Исследование об уголовном праве Русской Правды, С. Петербург: Типография ІІ Отд. С. Е. И. В. Канцелярии.

Липшиц, Елена Э. (1965): Эклога, Москва: Издательство Наука.

Милов, Леонид Васильевич (1998): Византийская Эклога и Пространная Русская Правда (проблемы рецепции), Ius Antiquum бр. 1, 113-119, https://docplayer.ru/71148797Vizantiyskaya-ekloga-i-prostrannaya-russkaya-pravda-problemy-recepcii.html, приступљено 16. 7. 2021.

Николић, Драган (2000): Древноруско словенско право, Београд: Службени лист CPJ.

Николић, Драган (2016): Закон судњи људем, Ниш: Центар за публикације Правног факултета Универзитета у Нишу, Центар за византијско-словенске студије Универзитета у Нишу.

Николић, Драган, Ђорђевић, Александар (2011): Законски текстови старог и средњег века, Ниш: Центар за публикације Правног факултета у Нишу.

Омельченко, Светлана Сергеевна (2008): Оскорбление и клевета в уголовном праве России XI-XVII вв, Актуальнье проблемы российкого права бр. 1, 240-246.

Памятники древне-русскаго каноническаго права (1908): Памятники древнерусскаго каноническаго права, ч. 1, ред. А. С. Павлов, Санкт-Петербург: Императорская археографическая комиссия.

Памятники права Киевского государства X-XII вв. (1952): Памятники русского nрава, Bbın. 1, сост А. А. Зимин, Москва: Юридическая литература.

Памятники права феодально-раздробленной Руси XII-XV вв. (1953): Памятники русского права, Bып. 2, сост А. А. Зимин, Москва: Юридическая литература.

Попов, Ардалион (1904): Суд и наказания за преступления против веры $u$ нравственности по русскому праву, Казань: Типо-литография Императорскаго Университета.

Пушкарева, Наталья Львовна (1989): Женщины Древней Руси, Москва: Мысль.

Пушкарева, Наталья Львовна (2011): Частная жизнь женщины в Древней Руси и Московии: невеста, жена, любовница, Москва: Издательство Ломоносовь. 
Пушкарева, Наталья Львовна (2012): Позорящие наказания для женщин: истоки и последствия гендерной асимметрии в русском традиционном и писаном праве, у: Муравьева, Марианна Георгиевна, Пушкарева, Наталья Львовна, Бытовое насилие в истории российской повседневности (XI-XXI вв.), Санкт-Петербург: Издательство Европейского университета в Санкт-Петербурге, 11-16.

Пушкарева, Наталья Львовна, Белова, Анна Валерьевна, Мицок, Натальа Александровна (2020): Сметая запреть: очерки русской сексуальной культуры XI-XX веков, Москва: Новое литературное обозрение, https://readli.net/chitatonline/?b=1085500\&pg=5, приступљено: 1. 08. 2021.

Ролдугина, Ирина (2021): Возникновение субкультуры проституции, https://arzamas.academy/materials/850, приступљено: 18. 6. 2021.

Романов, Петр Алексеевич (2021): Молодые годы: Начало славных дел (16891697), Честь, слава, империя (Труды, артикульы, переписка, мемуары), ВикиЧтение, https://law.wikireading.ru/55694, приступљено: 30. 11. 2021.

Российское законодательство X-XX веков, т. 2 (1984): Законодательство периода образования и укрепления Русского централизованного государства, у: Российское законодательство X-XX веков, m. 2, Отв. ред. А. Д. Горский, Москва: Юридическая литература.

Российское законодательство X-XX веков, т. 3 (1985): Акты Земских соборов, у: Российское законодательство $X-X X$ веков, т. 2, Отв. ред. А. Г. Маньков, Москва: Юридическая литература.

Семенникова, Любовь Ивановна (2009): Россия в мировом сообществе циивилизаций, Москва: Издательство КДУ.

Сергеевич, Василий Иванович (1910): Лекиии и исследования по древней истории русскаго права, С. Петербург: Типография М. М. Стасюлевича.

Словарь русского языка XI-XVII вв. (1983): Словарь русского языка XI-XVII вв. Выпуск 10 (Н-наятися), Москва: Наука.

Словарь русского языка XI-XVII вв. (1992): Словарь русского языка XI-XVII вв. Выпуск 18 (Потка - Преначальный), Москва: Наука.

Соборное уложение 1649 года (1987): Соборное уложение 1649 года, Текст, Коментарии, Руководитель авторского коллектива А. Г. Маньков (1987): Ленинград: Наука.

Соловјев, Александар Васиљевич (1980): Законик ичара Стефана Душана 1349. и 1354. година, Београд: САНУ.

Соловјев, Александар Васиљевич (1998): Историја словенских права; Законодавство Стефана Душана иара Срба и Грка, Београд: Службени лист СРЈ.

Статут велікага літоўскага 1588 (1989): Статут велікага літоўскага 1588 года. Тэксты. Даведнік. Каментарыі, Мінск: БелСЭ.

Стефанович, Петр Сергеевич (2004): Древнерусское понятие чести по памятникам литературы домонгольской Руси, Философия культуры, 63-87, http://drevnyaya.ru/vyp/stat/s2_16_9.pdf, приступљено 1.08. 2021.

Тарановски, Теодор (1996): Историја српског права у Немањићкој држави, Београд: Службени лист СРЈ.

Тихомиров, Михаил Николаевич (1941): Исследование о Русской Правде: происхождение текстов, Москва - Ленинград: Академия Наук СССР.

Тихомиров, Михаил Николаевич (1953): Пособие для изучения Русской Правды, Москва: Издательство Московского университета.

Томсинов, Владимир Алексеевич (2011): Соборное уложение 1649 года, Законодательство иаря Алексея Михайловича, Москва: Зерцало. 
Филиппов, Александр Никитич (1907): Учебник истории русскаго права, Юрьев: Типография К. Маттисена.

Хрестоматия памятников феудального государства и права стран Европы (1961): Хрестоматия памятников феудального государства и права стран Европь: Государство древних франков, Англо-Саксонское государство, Англия, Германия, Испания, Италия, Франция, Албания, Болгария, Венгрия, Польиа, Румыния, Чехия, Югославия, под ред. В. М. Корецкого, Москва: Юридеческая литература.

Чворовић, Зоран (2013): Кривично право у Уложенију изара Алексеја Михаиловича, Крагујевац: Правни факултет Универзитета у Крагујевцу (необјављена докторска дисертација).

Чворовић, Зоран (2014): Право и православље, Београд: Catena mundi. mundi.

Чворовић, Зоран (2018а): Душанов законик у руском огледалу, Београд: Catena

Чворовић, Зоран (2018б): Абортус као кривично дело у старовековним правима, канонима Цркве и у византијско-словенском праву, Црквене студије, 15/2018, 475-491.

Чворовић, Зоран (2018в): Саборно уложеније од 1649. године - угаони камен у развитку руског права, у: Увод у право Русије - Введение в право России, ур. М. Зиројевић и Н. Кршљанин, 67-82.

Чворовић, Зоран (2020): Рецепција Законоправила Светог Саве у Русији: разлози и околности, Зборник радова са научног скупа „,800 година аутокефалности Српске православне иркве, “ Косовска Митровица: Правни факултет Универзитета у Приштини са привременим седиштем у Косовској Митровици.

Щапов, Ярослав Николаевич (1971): Устав князя Ярослава и вопрос об отношении к византийскому наследию на Руси в середине XI в, Византийски й временник, т. 31, 71-78.

Щапов, Ярослав Николаевич (1972): Княжеские уставы и церковь в Древней Руси XI-XIV вв., Москва: Наука.

Яговец, Виктория В. (2009): Статус женщны в древнерусском обществе, Вестник Санкт-Петербургского Университета, Вып. 4, 144-151.

Ярмонова, Елена Николаевна (2013), Отдельные аспекты изменения порядка заключения брака в России с IX по XIX вв., Вопросы российского и международного права бр. 1, 95-122, http://publishing-vak.ru/file/archive-law-2013-1/5-yarmonova.pdf, приступљено: 16. 7. 2021.

Ярмонова, Елена Николаевна (2014): Похищение невесты как форма заключения брака на Руси в языческий период, Вопросы современой юруспруденщии: сб. ст. по матер XXXIX-XL междунар. науч.-практ. конференции, Новосибирск: СибАК, 23-27.

Artemis-Terzieva, Rossitisa (2004): Patriarchy. Y: Encyclopedia of Rape, ed. Smith, Merril D: Westport - Connecticut, London: Greenwood Press, 145-146.

Bartulović, Željko, Erent-Sunko, Zrinka, Pezelj, Vilna (2018): Spolno zlostavljanje i druga kaznena djela nasilja nad ženama u zakonicima srednjovjekovnog germanskog prava $\mathrm{s}$ naglaskom na Lex salica i Lex ribuaria, Zbornik Pravnog fakulteta Sveučilišta u Rijeci, vol. 39, br. 3, 1091-1118.

Bloch, Richard Howard (1991): Medieval Misogyny and the Invention of Western Romantic Love, Chicago, London: The University of Chicago Press.

Brownmiller, Susan (1993): Against Our Will: Men, Women and Rape, New York: Fawcett Columbine.

Divković, Mirko (1980): Latinsko-hrvatski riječnik, Zagreb: ITRO Naprijed (reprint izdanja iz 1900). 
Dunn, Carolina (2013): Stolen Women in Medieval England: Rape, Abduction, and Adultery, 1100-1500, New York: Cambridge University Press.

Eska, Charlene M. (2013): „Imbrued in their owne bloud“: Castration in Early Welsh and Irish Sources, y: Castration and Culture in the Middle Age, ed. Tracy, Larissa, Cambridge: D. S. Brewer, 149-173.

Field, Robin E. (2004): Rape Culture, y: Encyclopedia of Rape, ed. Smith, Merril D: Westport - Connecticut, London: Greenwood Press, 174-175.

Harris, Carissa (2021): 800 Years of Rape Culture, Aeon, 24. 5. 2021, https://aeon.co/essays/the-hypocrisies-of-rape-culture-have-medieval-roots, приступљено: 16. 11. 2021.

Ignjatović, Tanja (2018): Uticaj (anti)feminizma na politike i prakse prema muškom nasilju protiv žena - globalna i lokalna perspektiva, y: Feministička teorija za sve: Zbornik radova sa konferencije, Beograd: Institut za filozofiju i društvenu teoriju Univerziteta u Beogradu, Fakultet političkih nauka Univerziteta u Beogradu, 263-284.

Petričević, Paula (2008): Jedan Bog - jedan rod: odnos monoteističkih vjerskih zajednica prema ženskim ljudskim pravima, y: Neko je rekao feminizam? Kako je feminizam uticao na žene u XXI veku, Beograd: Heinrich Böll Stiftung Regionalna kancelarija za Jugoistočnu Evropu, 120-138.

Laiou, Angeliki E. (1993): Sex, Consent, and Corecion in Byzantium, y: Consent and Corecion to Sex and Marriage in Anicent and Medieval Societies, ed. Angeliki E. Laiou, Washington: Dumbarton Oaks, 109-221.

Pistono, Stephen P. (1989): Rape in Medieval Europe, Atlantis, No. 2/1989, https://journals.msvu.ca/index.php/atlantis/article/view/4287/3531, приступљено: 18.11. 2021, 36-43.

Schmid, Stephanie L. (2004): Rape Law, y: Encyclopedia of Rape, ed. Smith, Merril D: Westport - Connecticut, London: Greenwood Press, 186-189.

Schmidt, Heather (2004): Rape Myths, y: Encyclopedia of Rape, ed. Smith, Merril D: Westport - Connecticut, London: Greenwood Press, 191-193.

Scholz, Susanne (2004): Religion, y: Encyclopedia of Rape, ed. Smith, Merril D: Westport - Connecticut, London: Greenwood Press, 206-209.

Tacit, Publije Kornelije (1969): Germanija, Agrikola, Razgovori o govornicima, Beograd: Rad.

Tertulliani (2003), De Cultu Feminarum Libri Duo, Liber II, Text edited by Marie TURCAN, Sources Chrétiennes 173 (1971). Scanned by Roger Pearse, 2003, https://www.tertullian.org/latin/de_cultu_feminarum_2.htm, приступљено: 16.07. 2021.

Walker, Garthine (2013): Sexsual violence and rape in Europe, 1500 - 1750, y: The Routledge History of Sex and the Body: 1500 to the Present, ed. Sarah Toulalan, Kate Fisher, London, New York: Routledge, 429-443. 


\section{Zoran Čvorović}

\section{PROTECTION OF WOMEN BY RUSSIAN MEDIEVAL CRIMINAL LAW}

The work deals with the legal position of a woman in medieval Russia from the perspective of criminal regulations that protect the life, honor, and health of a woman. Based on analysis of numerous legal monuments, as well as monuments of legal practice, on the example of Russian medieval law the work reassess the thesis of feminist social theory that Christianization has led to a deterioration in the legal and social status of women. 